Journal of British Studies 61 (January 2022): 50-82. doi:10.1017/jbr.2021.125

(C) The Author(s), published by Cambridge University Press on behalf of the North American Conference on British Studies. This is an Open Access article, distributed under the terms of the Creative Commons Attribution licence (https://creativecommons.org/licenses/by/4.0/), which permits unrestricted re-use, distribution, and reproduction in any medium, provided the original work is properly cited.

\title{
Waifs and Strays: Property Rights in Late Medieval England
}

\section{Jordan Claridge $\odot$ and Spike Gibbs}

\begin{abstract}
This article provides new insights into long-standing debates on lord-tenant relations in medieval England and how they were negotiated through the manorial court. We examine an institution, which we term the stray system, that facilitated cooperation between lords and tenants to manage stray livestock. Specifically, we argue that the stray system is a clear example of a public good. In this context, the system was a social benefit provided by lords to their tenants as a collective. In a world where most of the population was dependent on agriculture for their livelihoods, any potential damage to a crop would have been of real concern. However, in managing the threat of wandering livestock, the property rights of owners had to be clearly protected to avoid disputes over ownership. The manorial court's management of strays provided an institution to resolve these countervailing pressures. Ultimately, that system helped to protect a community's arable land-the most vital source of income for lords and tenants alike-while simultaneously assuring the property rights of those who had lost important capital assets in the form of livestock.
\end{abstract}

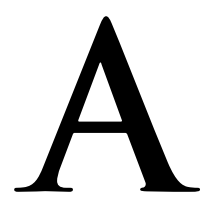

$\mathrm{t}$ the manor court of Little Downham, Cambridgeshire, in a session held 27 September 1392, the lord's reeve, Robert Rote, presented eight "stray" animals. He declared that "one mare, one brown mare with a foal, one grey mare with a foal, one grey female foal, and two black steers" had appeared inside the lordship around the feast day of the Decollation of Saint John the Baptist (29 August) about a month earlier. The court roll described these animals as de ext[ra]y and declared that no one had yet come to claim them. The court therefore ordered that the discovery of these stray beasts was to be advertised ("proclaimed," in the legal jargon) around the local community. ${ }^{1}$ The story was

Jordan Claridge is an assistant professor in the Department of Economic History, London School of Economics and Political Science; Spike Gibbs is an LSE Fellow at the Department of Economic History, London School of Economics and Political Science. We are grateful for feedback received at the following meetings: the Economic History "Brown Bag" seminar and "Sowing the Seeds VI" workshop at the London School of Economics; the Oxford Medieval Economic and Social History Seminar; the 2018 Economic History Society Conference; the University of Groningen Economics Seminar; and the Cambridge Medieval Economic and Social History Seminar. We are grateful to Alan Rose for providing examples from the manor of Willington and to Jean Birrell for providing examples from the manor of Alrewas. We are also grateful to Mark Bailey, Jean Birrell, and Patrick Wallis, who read earlier drafts of this article, and to two anonymous referees. As always, any errors are our own. Please direct any correspondence to j.claridge@lse. ac.uk.

${ }^{1}$ Court Rolls of the Manor of Little Downham, September 1392, Ely Diocesan Records, C11/1/3, m.30, 27 Cambridge University Library, Cambridge. (The collection is hereafter abbreviated as EDR; all records cited from this collection are court rolls.) 
continued in the following court two months later. On 5 December, William Lutgate of Doddington came with "six hands" (that is, six men to support his claim) to prove ownership of one of the horses, a "whitblakspottyd" mare. William paid a fee of $12 \mathrm{~d}$. to the lord, and the mare was released to him. ${ }^{2}$ However, the remaining seven animals remained unclaimed, and an official was ordered to proclaim them once more. This happened again in courts of February and July 1393. ${ }^{3}$ It was not until a court of 1 September 1393 that the story ends. The animals having remained unclaimed inside the lordship of Little Downham for a year and a day, the court stated that they would become the lord's property as forfeited chattels. ${ }^{4}$

Events like these were not occasional curiosities; the narrative outlined above is simply one example of a process that played out thousands of times in manor courts across late medieval England. Even a superficial examination of manorial documents reveals that stray animals were an ever-present nuisance of everyday life for rural communities. The frequency of references in court rolls illustrates just how much time manorial courts spent administering the stray system, ${ }^{5}$ and the sheer number of bylaws dealing explicitly with the management of loose livestock ${ }^{6}$ reveals the deep concern that medieval communities shared about animals damaging their crops. From the lord's perspective, strays were not only a threat to open-field crops sown by them and their tenants but were also a significant potential source of livestock for their own demesnes (lords' personal farms, as opposed to the lands of their tenants). ${ }^{7}$ However, despite the centrality of stray animals to medieval rural life, the nature of the system that administered them remains poorly understood. ${ }^{8}$

In this article, we have two aims. Through the analysis of a substantial sample of manorial court rolls, spanning the years 1274 to 1453 and containing a total of 1,781 court sessions, we illustrate and explicate the stray system. We describe the legal framework that undergirded the system and explore its many levels of operation, from the royal franchises that granted the rights to claim strays to the courts that applied and mediated these rights on the manor, and finally to the individuals who worked in the system and made the system work. Secondly, we use the stray

25 December 1392, EDR, Cll/1/3, m.31.

${ }^{3} 28$ February 1393, EDR, Cll/1/3, m.31; 1 July 1393, EDR, C11/1/3, m.31.

${ }^{4} 1$ September 1393, EDR, C11/1/3, m.32.

5 The manor court at Little Downham dealt with stray animals so frequently that these cases account for up to 8 percent of all presentments made by officials from the 1310s to 1580s. This was not a regional phenomenon, as up to 22 percent of all presentments made at Worfield, in Shropshire, from the 1320s to 1590 s concerned strays. See court rolls at EDR, C11/1/1-3, Cl1/2/4-6, and C11/3/7-11; see also Court Rolls of the Manor of Worfield, P314/W/1/1/34-831, Shropshire Archives, Shrewsbury. (Hereafter this repository is abbreviated as SA; all references cited are court rolls).

${ }^{6}$ For example, out of 195 bylaws surveyed in Warren Ault's authoritative study, thirty-three specifically concerned the management of horses. See Warren O. Ault, Open-Field Farming in Medieval England: $A$ Study of Village By-Laws (London, 1972).

7 Jordan Claridge, "The Role of Demesnes in the Horse Trade of Late Medieval England," Agricultural History Review 65, no. 1 (2017): 1-19, at 10, esp. table 3.

${ }^{8}$ This is despite recent interest in how medieval local communities administered analogous systems like shipwreck. See Tom Johnson, "Medieval Law and Materiality: Finders, and Property on the Suffolk Coast, ca. 1380-1410," American Historical Review 102, no. 2 (2015): 407-32; Tom Johnson, "The Economics of Shipwreck in Late Medieval Suffolk," in Custom and Commercialisation in English Rural Society, 13001800, ed. J. P. Bowen and A. T. Brown (Hatfield, 2016), 121-38. 
system to contribute to recent discussions of the role of manorial structures in village communities and what they reveal about lord-tenant relationships.

Specifically, we argue that the stray system is a clear example of a public good. Although strays could be forfeit to the lord, and so appear to have been a seigniorial perk, our assessment of the operation and the economics of the stray system in practice reveals that lords and tenants collaborated to provide this service for their community. Why was such a public good necessary on medieval manors? Stray animals represented a significant risk to the arable land held by both lords and tenants, and managing strays was thus of vital importance for the whole community. In a world where most of the population was reliant on agriculture-already vulnerable to the vagaries of the environment ${ }^{9}$ - to provide a basic livelihood, any potential damage to a crop would have been a very real concern. While in the modern period interventions such as barbed wire protected private agricultural land and mitigated this problem, limited medieval technology and the communal nature of agriculture required a different solution. ${ }^{10}$ However, in managing the threat of wandering livestock, the property rights of owners had to be clearly protected to avoid violent disputes stemming from accusations of theft and conflict over ownership. The manorial court's management of strays provided an institution to resolve these countervailing pressures. Ultimately, it provided an imperfect but workable system that added an element of protection to crops in the fields while offering a tangible form of redress for the accidental loss of livestock.

\section{HISTORIOGRAPHY: LORD-TENANT DYNAMICS AND THE ROLE OF MANORIAL STRUCTURES IN MEDIEVAL ENGLAND}

The relationship between lords and tenants has been a long-standing subject in the historiography of the late Middle Ages. A particularly influential interpretation, chiefly developed in the postwar period, is a Marxist explanation of late medieval economic and social development arguing that the relationship between lord and tenants was the primary determinant of economic well-being. ${ }^{11}$ This model proposes that the feudal mode of production fundamentally involved a process of "surplus extraction," in which lords secured their incomes through expropriating the product

\footnotetext{
${ }^{9}$ For examples of recent scholarship that consider the economic impact of environmental factors in the medieval world, see Bruce M. S. Campbell, The Great Transition: Climate, Disease and Society in the LateMedieval World (Cambridge, 2016), 1-29; Philip Slavin, "Market Failure during the Great Famine in England and Wales (1315-1317)," Past and Present, no. 222 (2014): 9-49.

${ }^{10}$ For a discussion of the relationship between barbed wire and agricultural productivity in the nineteenth-century American plains, see Richard Hornbeck, "Barbed Wire: Property Rights and Agricultural Development," Quarterly Journal of Economics 125, no. 2 (2010): 767-810.

${ }^{11}$ Phillipp R. Schofield, Peasants and Historians: Debating the Medieval English Peasantry (Manchester, 2016), 84-116; John Hatcher, "Lordship and Villeinage before the Black Death: From Karl Marx to the Marxists and Back Again," in Peasants and Lords in the Medieval Economy: Essays in Honour of Bruce Campbell, ed. Maryanne Kowaleski, John Langdon, and Phillipp R. Schofield (Turnhout, 2015), 113-45, at 119-31; John Hatcher and Mark Bailey, Modelling the Middle Ages: The History and Theory of England's Economic Development (Oxford, 2001), 66-120; R. H. Hilton, introduction to The Brenner Debate: Agrarian Class Structure and Economic Development in Pre-industrial Europe, ed. T. H. Aston and C. H. E. Philpin (Cambridge, 1985), 1-9, at 2-5.
} 
created by their tenants. ${ }^{12}$ The form of this extraction, which varied between places and over time, consisted of some combination of rents and jurisdictional privileges. ${ }^{13}$ In this schema, the relations between lords and tenants were inexorably conflictual. ${ }^{14}$ At least some of these jurisdictional privileges could, it is argued, be levied at the lord's will and thus had "an arbitrary and unexpected character." 15 Often, the lord's manor court has been seen as a crucial instrument for the extraction of these rents and privileges. The court gathered information about who owed seigniorial dues and punished those who failed to render them, and therefore acted as a key tool of oppression. ${ }^{16}$

However, more recent contributions, written from both Marxist and revisionist perspectives, have tended to complicate this view of manorial institutions. A crucial focus has been on the role of custom as a constraint on lordship. These were local norms and practices that had developed over centuries and defined the rights of lords more specifically than theoretical legal entitlements. ${ }^{17}$ For example, Mark Bailey has demonstrated that tallage, typically the right of lords to charge an extraordinary tax on their tenants, was not a "monetary facet of lordly power" that could be levied at will, as R. H. Hilton had claimed, ${ }^{18}$ but was in reality "neither arbitrary nor unpredictable" and "heavily influenced by custom." 19 Local customs were a powerful force that acted to routinize and fix both the land rents and feudal dues that tenants could expect to pay to their lords. ${ }^{20}$ Significantly, manorial custumals and courts provided key channels through which tenants could define and shape custom and therefore were a crucial part of this process. ${ }^{21}$

${ }^{12}$ Maurice Dobb, "From Feudalism to Capitalism," in The Transition from Feudalism to Capitalism, ed. R. H. Hilton (London, 1976), 158-71, at 165; R. H. Hilton, "Peasant Movements in England before 1381," Economic History Review, 2nd ser., 2, no. 2 (1949): 117-36, at 118; R. H. Hilton, Bond Men Made Free: Medieval Peasant Movements and the English Rising of 1381 (London, 1973), 42; Robert Brenner, "Agrarian Class Structure and Economic Development in Pre-industrial Europe," Past and Present, no. 70 (1976): 30-75, at 31-32.

${ }^{13}$ For a more detailed discussion of feudal incidents, see Mark Bailey, The Decline of Serfdom in Late Medieval England: From Bondage to Freedom (Woodbridge, 2014), 16-61.

${ }^{14}$ Hilton, Bond Men Made Free, 61-62.

${ }^{15}$ Hilton, 84. See also Hilton, introduction to Brenner Debate, 5; R. H. Hilton, introduction to The Transition from Feudalism to Capitalism, ed. R. H. Hilton (London, 1976), 1-19, at 15-17.

${ }^{16}$ Christopher Dyer, Lords and Peasants in a Changing Society (Cambridge, 1980), 265; R. H. Hilton, The English Peasantry in the Later Middle Ages: The Ford Lectures and Related Studies (Oxford, 1975), 23137; Hilton, "Peasant Movements in England before 1381," 120; Ralph Evans, "Whose Was the Manorial Court?," in Lordship and Learning: Studies in Memory of Trevor Aston, ed. Ralph Evans (Woodbridge, 2004), 155-68, at 168; Harry Kitsikopoulous, "England," in Agrarian Change and Crisis in Europe, 1200-1500, ed. Harry Kitsikopoulous (New York, 2012), 23-56, at 46-47.

${ }^{17}$ John Hatcher, "English Serfdom and Villeinage: Towards a Reassessment," Past and Present, no. 90 (1981): 3-39, at 8-14; Mark Bailey, "Villeinage in England: A Regional Case Study, c. 1250-c.1349," Economic History Review 62, no. 2 (2009): 430-57, at 451-54; J. Z. Titow, English Rural Society, 1200-1350 (London, 1969), 58-60.

${ }^{18}$ R. H. Hilton, A Medieval Society: The West Midlands in the Later Middle Ages (London, 1966), 144 47; Hilton, English Peasantry in the Later Middle Ages, 199, 231, 237; Hilton, "Peasant Movements," 11920,130 .

${ }^{19}$ Mark Bailey, "Tallage-at-Will in Later Medieval England," English History Review 134, no. 566 (2019): 25-58, at 57 .

${ }^{20}$ Stephen H. Rigby, English Society in the Later Middle Ages: Class, Status and Gender (Basingstoke, 1995), 29; Hatcher and Bailey, Modelling the Middle Ages, 105.

${ }^{21}$ Jean Birrell, "Manorial Custumals Reconsidered," Past and Present, no. 224 (2014): 3-37, at 33-37; Mark Bailey, The English Manor, c.1200-c.1500 (Manchester, 2002), 174. 
Other studies have challenged the notion of a strictly extractive lord-tenant dynamic by examining the ways in which manorial structures could work positively to serve the purposes of seignorial tenants. ${ }^{22}$ This new direction has been partly the result of a shift away from analyzing peasants in terms of their relationship with lords to examining them as economic actors engaged in a far wider network of marketbased associations. ${ }^{23}$ Although historians such as Hilton working in a Marxist framework, were always aware that peasants engaged in economic activities beyond paying rents to their lords, ${ }^{24}$ newer studies from a "commercialization" perspective have tended to emphasize peasant economic activity as a crucial driver of economic development in the late Middle Ages. ${ }^{25}$ In making this case, these studies argue that many manorial structures and institutions actually helped peasants by creating a constructive environment for production, investment, and trade. ${ }^{26}$

John Langdon's exhaustive study of medieval English milling articulates such a revisionist interpretation. ${ }^{27}$ Rather than viewing millsuit, the obligation of all tenants (as opposed to only unfree, or customary, tenants) to use the lord's mill, as a form of seigniorial extraction, Langdon demonstrated that millsuit violations were rarely recorded in court records. He suggested that this feudal practice was not enforced very actively, concluding, "Customers generally came to mills because they wanted to, not because they were forced there." ${ }^{28} \mathrm{He}$ goes so far as to suggest that lords may have had a "paternalistic attitude to their tenants," and tenants may have actually appreciated the easy access to a local mill that many lords provided. ${ }^{29}$

Langdon's exploration of the milling industry goes some way toward rehabilitating the image of the manor court. Courts provided a direct channel from tenants to lords through which the former could raise concerns to the latter about the unfair dealing of millers or even the need for the improvement or refurbishment of community mills. ${ }^{30}$ Such a view can be fit into a wider literature that has demonstrated the facilitative role that courts could have in medieval English village 27.

22 J. A. Raftis, Peasant Economic Development within the English Manorial System (Montreal, 1997), 11-

${ }^{23}$ Schofield, Peasants and Historians, 117-41.

${ }^{24}$ Hilton, English Peasantry in the Later Middle Ages, 37-53; Schofield, Peasants and Historians, 118-23.

${ }^{25}$ Richard H. Britnell, The Commericialisation of English Society, 1000-1500, 2nd ed. (Manchester, 1996), xiii-xvi, 228-38; John Langdon and James Masschaele, "Commercial Activity and Population Growth in Medieval England," Past and Present, no. 190 (2006): 35-81; Hatcher and Bailey, Modelling the Middle Ages, 121-73.

${ }^{26}$ Hatcher and Bailey, Modelling the Middle Ages, 139-42. See also the work of Richard Britnell, who argued that lords were important pioneers in establishing markets through the purchase of royal franchises in this period. Richard H. Britnell, "The Proliferation of Markets in England, 1200-1349," Economic History Review 34, no. 2 (1981), 209-21; Britnell, Commercialisation of English Society, 1000-1500, 23033.

27 John Langdon, Mills in the Medieval Economy: England, 1300-1540 (Oxford, 2004)

${ }^{28}$ Langdon, Mills in the Medieval Economy, 283-87.

${ }^{29}$ Langdon, Mills in the Medieval Economy, 290. Richard Britnell also argues for the notion of "paternalism" in his discussion of the establishment of smaller markets by lords. See Britnell, "Proliferation of Markets in England, 1200-1349," 221.

${ }^{30}$ Spike Gibbs, "Lords, Tenants and Attitudes to Manorial Officeholding, c.1300-c.1600," Agricultural History Review 67, no. 2 (2019): 155-74, at 166-67; Langdon, Mills in the Medieval Economy, 183-84, 290. 
communities. ${ }^{31}$ In this paradigm, courts could work on both individual and collective levels. In terms of individual tenants, the manor court had a significant role, most pronounced in East Anglia, in transferring customary land (the land of unfree, or villein, tenants as opposed to free tenants). ${ }^{32}$ Property transfers not only facilitated land sales in an active market, but also allowed tenants to fashion complex inheritance strategies. ${ }^{33}$ For both free and unfree tenants, manor courts also provided a forum for cheap and easily accessed interpersonal litigation. ${ }^{34}$ Ultimately, manorial courts allowed tenants to enter into enforceable contracts that, in turn, fostered the growth of an array of economic activities such as a burgeoning peasant credit market. ${ }^{35}$ Tenants also used manorial courts for a wider array of collective processes, such as registering and enforcing bylaws. These were sets of regulations drawn up by village communities concerning common lands, grazing rights, and other collective concerns. The manor court was the primary venue that dealt with these issues in the late fourteenth and fifteenth centuries. ${ }^{36}$ Thus, historiography has shifted in recent years to seeing the manor court as a vital institution that provided tenants with an array of commercial opportunities while also ensuring collective protections of common resources. ${ }^{37}$

Lords did generate revenues from all of the "services" discussed above. They took fees for land transfers, charged for hearing interpersonal suits, and were paid for use of their mills. However, there is growing recognition that manorial institutions, particularly courts, also played a positive role in village communities. They did so not only by providing ways for tenants to constrain lords using the power of custom but also by facilitating a range of processes essential to the day-to-day economic

${ }^{31}$ Sherri Olson, A Chronicle of All Happens: Voices from the Village Court in Medieval England (Toronto, 1996), 21-26.

${ }^{32}$ Chris Briggs and Phillipp R. Schofield, "The Evolution of Manor Courts in Medieval England, c.1250-1350: The Evidence of the Personal Actions," Journal of Legal History 41 no. 1 (2020): 1-28, at 2; Bruce M. S. Campbell, "Population Pressure, Inheritance and the Land Market in a FourteenthCentury Peasant Community," in Land, Kinship and Life-Cycle, ed. R. M. Smith (Cambridge, 1984), $87-134$, at 107.

${ }^{33}$ P. D. A. Harvey, "Conclusion," The Peasant Land Market in Late Medieval England, ed. P. D. A. Harvey (Oxford, 1984), 328-56, at 349-53; Lloyd Bonfield and L. R. Poos, "The Development of the Deathbed Transfers in Medieval English Manor Courts," in Medieval Society and the Manor Court, ed. Zvi Razi and Richard Smith (Oxford, 1996), 117-42; Jane Whittle, The Development of Agrarian Capitalism: Land and Labour in Norfolk, 1440-1580 (Oxford, 2002), 167-77.

${ }^{34}$ Briggs and Schofield, "Evolution of Manor Courts," 2, 5-6; Chris Briggs and Phillipp R. Schofield, "Understanding Edwardian Villagers' Use of Law: Some Manor Court Litigation Evidence," Reading Medieval Studies, no. 40 (2014): 117-39, at 128; Zvi Razi and R. M. Smith, "The Origins of the English Manorial Court Rolls as a Written Record: A Puzzle," in Razi and Smith, Medieval Society and the Manor Court, 36-68, at 45-68.

${ }^{35}$ Chris Briggs, "Manor Court Procedures, Debt Litigation Levels, and Rural Credit Provision in England, c.1290-c.1380," Law and History Review 24, no. 3 (2006): 519-58, at 550-58; Chris Briggs, "The Availability of Credit in the English Countryside, 1400-1480," Agricultural History Review 56, no. 1 (2008): $1-24$, at 24.

${ }^{36}$ Warren O. Ault, "Open-Field Husbandry and the Village Community: A Study of Agrarian By-Laws in Medieval England," Transactions of the American Philosophical Society 55, no. 7 (1965): 1-102, at 11-54; Warren O. Ault, "The Vill in Medieval England," Proceedings of the American Philosophical Society 126, no. 3 (1982): 188-221, at 195-97.

${ }^{37}$ For the most recent articulation of this argument covering the full breadth of the historiography, see Mark Bailey, After the Black Death: Economy, Society, and the Law in Fourteenth-Century England (Oxford, 2021), 44-46. 
and social lives of rural inhabitants. In this latter role, courts helped to create a commonality between lords and tenants, who collaborated to achieve the common objective of providing an institutional environment conducive to agricultural production and commerce.

\section{THE LEGAL FRAMEWORK OF THE STRAY SYSTEM}

The stray system offers a case that powerfully illustrates how lords and tenants could use manorial institutions cooperatively to facilitate economy activity. While every manorial lord had the right to hold a manor court, not every lord had the right to claim stray animals. This particular entitlement was part of a larger set of privileges, called franchises, that typically belonged to the crown but could be granted to lords or claimed by them through immemorial usage. ${ }^{38}$ The famous legal treatise Bracton places the franchise of strays alongside those of wrecks and great fish as res nullius: things that "belong to the lord king because of his privilege or to those whom the king has granted such liberty."39

Other franchises included relatively common grants such as the view of frankpledge and the assize of bread and ales. The former allowed lords to administer the tithing system, a law and order mechanism that made ten men responsible for their fellows' behavior, ${ }^{40}$ while the latter empowered lords to monitor and regulate the sale of bread and ale. However, some franchises were more unusual. The right to take strays was an exalted privilege, alongside return of writs (allowing the lord to perform duties usually undertaken by royal officials), infangthief (allowing the lord to hang thieves caught red-handed within the manor), outfangthief (allowing the lord to hang inhabitants of the manor even if they committed crimes abroad), felony forfeiture (allowing lords to take both stolen goods and the chattels of convicted felons), and wreck (allowing lords to profit from items washed up from the sea). ${ }^{41}$ These more privileged franchises often came as a package. ${ }^{42}$

${ }^{38}$ Frederick Pollock and Frederic William Maitland, The History of English Law before the Time of Edward I, vol. 1 (Cambridge, 1895), 558-59; John Baker, Introduction to English Legal History, 5th ed. (Oxford, 2019), 31, 413-14; Donald W. Sutherland, Quo Warranto Proceedings in the Reign of Edward I: 1278-1294 (Oxford, 1963), 3-6.

39 Samuel E. Thorne, ed., Bracton on the Laws and Customs of England, vol. 2 (Cambridge, MA, 1968), 339.

40 Sutherland, Quo Warranto, 3; Phillipp R. Schofield, "The Late Medieval View of Frankpledge and the Tithing System: An Essex Case Study," in Razi and Smith, Medieval Society and the Manor Court, 408-49, at 408 .

${ }^{41}$ Pollock and Maitland, History of English Law before the Time of Edward I, 567-72; Michael Clanchy, "The Franchise of the Return of Writs," Transactions of the Royal Historical Society, no. 17 (1967): 5982; J. B. Post, "Local Jurisdictions and the Judgement of Death in Late Medieval England," Criminal Justice History, no 4 (1983): 1-21; Baker, English Legal History, 543; Spike Gibbs, "Felony Forfeiture at the Manor of Worfield, c.1370-C.1600," Journal of Legal History 33, no. 3 (2018): 253-77; Johnson, "Medieval Law and Materiality"; Johnson, "Economics of Shipwreck."

${ }^{42}$ For example, see Eileen Power, Medieval English Nunneries, c.1275-1535 (Cambridge, 1922), 103-4; "Henry VI: January 1442," in Parliament Rolls of Medieval England, ed. C. Given-Wilson et al. (Woodbridge, 2005); The Parliament Rolls of Medieval England, http://www.sd-editions.com/PROME; F. Blomefield, An Essay towards a Topographical History of the County of Norfolk, vol. 6 (London, 1807), 108-11, British History Online, accessed 14 September 2021, http://www.british-history.ac.uk/ 
How was the franchise of stray exercised? Setting a trend that later writers would follow, Bracton wrote simply that stray livestock must be animals "which no one pursues, claims or avows." ${ }^{43}$ Another legal treatise, Britton, provides more detail. It places strays within the category of "those things lost and found above ground." More importantly, the treatise defines a specific window of time for reclaiming lost livestock, stating that "if the owner demand them within the year and day, and can prove them to be his property, they shall be delivered to him." $" 44$ Alternatively, "waifs or estrays, not challenged within the year and day, shall belong to the lord of the franchise." 45 The text goes on to emphasize that forfeiture to the lord was only legitimate if the animal had been clearly proclaimed throughout the 366-day period, outlining that "if the lord did not cause the beast so found to be publicly cried in manner aforesaid, then no time shall be run against the owner of the thing or beast, to bar him from replevying it whenever he pleases." 46 So, according to Britton, for lords to claim a stray legally, they had to keep stray beasts for 366 days and also to ensure that word of the animal's discovery was appropriately advertised for this period. Only then, if the animal remained unclaimed, would it become the legal property of the claiming lord.

Importantly, lords could only exercise the franchise of stray (as with all other such franchises) within the boundaries of their own manor. ${ }^{47}$ This restriction is exemplified in 1394 at Little Downham in Cambridgeshire, when the manor's jury specifically defined the territory in which the lord had the right to collect strays in the surrounding fenland. ${ }^{48}$ The defining of such stray "catchment areas" could, and often did, lead to conflict between lords. The Year Books note several conflicts over who could exercise the franchise of strays on a particular manor. ${ }^{49}$ These disputes illustrate that not only did lords seek to protect their rights to strays but also that the crown regulated lords' claims to these privileges.

To exercise the franchise of strays illegitimately could incur heavy penalties, as a trespass case from 1382 at the court of common pleas, replete with lords and their officials, illustrates. The case hinged on who had the right to take strays within the vill of Shawell, Leicestershire. A stray mare was seized by William de Garton, the

topographical-hist-norfolk/vol6/ppl08-111; H. C. Maxwell Lyte, ed., Calendar of Close Rolls, Richard II, vol. 2, 1381-85 (London, 1920), 631-35; Frances. M. Page, The Estates of Crowland Abbey: A Study in Manorial Organisation (Cambridge, 1934), 17.

${ }^{43}$ Thorne, Bracton on the Laws and Customs of England, 339.

${ }^{44}$ Francis Morgan Nichols, ed., Britton: The French Text Carefully Revised with an English Translation, Introduction and Notes, vol. 2 (London, 1865-66), 67 (our emphasis). This was also the period in which owners were allowed to reclaim goods that had been washed up as shipwreck. See Johnson, "Economics of Shipwreck," 122.

${ }^{45}$ Nichols, Britton, 67-68.

${ }^{46}$ Nichols, 68.

47 Baker, English Legal History, 30; Sutherland, Quo Warranto, 3.

483 December 1394, EDR, C1l/1/3, m.36.

49 Such conflicts occurred between the abbot of Waltham and the Prebendary of St. Paul's in 1345, and in 1467 between the prior of Spalding and a bailiff of the Duchy of Lancaster. See the following in Boston University School of Law, Legal History: The Year Books, Easter 19 Edward III, fols. RS199-23, 43, Seipp no. 1345.096rs; Trinity 7 Edward IV, fols. 10b-12b, 2, Seipp no. 1467.032, https://www.bu. edu/phpbin/lawyearbooks/search.php (access records by Seipp number). At this point, the Duchy of Lancaster was in the crown's hands. 
bailiff of the Prior of the Hospital of St. John of Jerusalem in England. However, Sir John de Crophill brought suit claiming that he had the right to strays in Shawell and that his official had (lawfully) seized the mare before William had subsequently taken it. ${ }^{50}$ William responded by arguing that, in his capacity as bailiff, he had lawfully seized the mare on behalf of his lord, who held the right to strays. Ultimately, the court decided that John's bailiff had seized the mare lawfully within his lordship. ${ }^{51}$ William was ordered to pay damages of one hundred shillings for illegally attempting to exercise the franchise of strays where he was not entitled to do so. Similar disputes are mentioned occasionally in manorial court rolls, when officials of one manor accused neighboring manors of illicitly seizing strays. ${ }^{52}$ For instance, in 1307 at the manor of Wakefield in Yorkshire, the court ordered that Sir Thomas de Burgh, a subtenant of the earl holding the nearby manor of Waleton, be distrained for retaining two stray horses "because no one has waif in the Earl's liberty, save the Earl himself." 53

Disputes often hinged on identifying where an animal had first been taken as a stray. This point was an issue in asserting property rights over possessions that could wander between manors. Some court rolls even record complaints about potential strays lost to rival local lords. For instance, in 1393, jurors at Tottenham Pembrokes in Middlesex presented that an exceptionally valuable grey horse had appeared on the manor in May but that it had then escaped into an adjacent manor held by Adam Franceys, where it was arrested by Adam's bailiff. ${ }^{54}$ From the other perspective, at Bradford (Yorks.) around 3 May 1360, the bailiff arrested a stray horse and placed it in the manor's common pasture. Subsequently, around 25 December 1360, this same horse was taken by the bailiff of the neighboring manor of Morley. The bailiff of Morley came to Bradford's manor court and argued that he was justified in taking the animal because it had first wandered in a place called "Rensthaghe outside Bradfordale" before 3 May and he had arrested the stray "in the park of . . Morley." 55

The legal history of the franchise of strays remains a topic that could be fruitfully subjected to further analysis. ${ }^{56}$ However, for the purposes of this article, three relevant and important conclusions arise from this brief investigation. Firstly, the right to take strays was often held by the most powerful lords, often in combination

${ }^{50}$ This claim to rights over strays took place in a wider dispute over jurisdiction with John de Crophill "not admitting that the prior . . has any lordship or view of frankpledge in the aforesaid vill." See Morris S. Arnold, ed., Select Cases of Trespass from the King's Courts, 1307-1399, vol. 2 (London, 1987), 251-52.

${ }^{51}$ Arnold, Select Cases of Trespass, 251-52.

523 December 1394, EDR, C11/1/3, m.36; 12 July 1440, EDR, C11/1/6, m.29. Obviously, these cases are subjective. Such seizures would only be illegal from the perspective of the lord in whose court it was presented.

${ }^{53}$ William Paley Baildon, ed., Court Rolls of the Manor of Wakefield, 1297-1309 (Cambridge, 1906), 42, $67,70,80$. (Unless otherwise noted, after first full citation to the volumes of court rolls of the various manors, the short citation form is the manor name and date range of the court rolls.)

${ }^{54}$ R. Oram, ed., Court Rolls of the Manors of Bruces, Dabeneys, Pembrokes (Tottenham), 1 Richard II to 1 Henry IV (1377-1399) (Tottenham, 1961), 282.

55 Court Rolls of the Manor of Bradford (all subsequent references to this collection are court rolls), 12 November 1360, The National Archives, DL 30/129/1957, m.51. (Hereafter this repository is abbreviated as TNA.)

${ }^{56}$ In particular, although beyond the scope of this article, it would be interesting to know more about how stray animals were treated in areas where the right to collect them remained with the crown. 
with a portfolio of other rights. If any lords could have squeezed a surplus from their tenants, it would surely have been the ones with these extensive legal rights. Secondly, lords were active in defending their rights to strays. They utilized both their manor courts and royal jurisdictions to exercise their franchises and to resolve disputes in which strays had crossed manorial boundaries. Thirdly, legal theorists had clear guidelines on how the franchise of strays should be exercised. Of course, legal theory does not necessarily reflect legal practice. In the next section, we address this issue by close examination of the way that strays were processed through manorial courts.

\section{THE OPERATION OF THE STRAY SYSTEM: LORDS, TENANTS AND CLAIMANTS}

Our analysis, below, of the stray system at the manorial level, is based on 1,066 observations of strays systematically drawn from surviving court rolls of nine manors across medieval England. ${ }^{57}$ Little Downham in Cambridgeshire, Wakefield in West Yorkshire, and Worfield in Shropshire were chosen because their court rolls survive in large numbers over long periods of time. Located in the North, the Midlands, and East Anglia, and with both ecclesiastical (Downham) and aristocratic (Wakefield and Worfield) lords, these manors give the study breadth in terms of both geography and lordship. These manors have been supplemented by shorter series of rolls from other manors from the Thames Basin region, which include manors held by the crown and religious houses.

The sample has some limitations. Most of the court rolls are drawn from either the pre- or post-Black Death period, with only one short series for Bradford crossing this divide. The composition of our sample presents some difficulty in measuring change over time in terms of the frequency or types of stray animals reported in courts. The growth of the pastoral sector and the proliferation of demesne leasing after the Black Death ${ }^{58}$ may have led manor courts to take a greater interest in stray animals. However, our sample cannot provide direct insights on such trends. Similarly, all except one of the manors were characterized by common field systems or common field systems with limited enclosure, and it seems logical to suggest that straying may have been a less pressing issue in communities with higher levels of enclosure. These issues await further investigation. Despite the heterogeneity of our sample and the almost two centuries surveyed, the stray system we outline seems to have been remarkably uniform, suggesting our conclusions are meaningful on a national scale.

The stray system had four fundamental stages. If the most direct route was followed, a stray was found, presented in court, advertised to neighboring communities, and finally either claimed by its owner or, if unclaimed for year and a day, forfeit to the lord. There were, however, a number of local peculiarities on any given manor as well as multiple opportunities for individuals to try to cheat the system. Both factors could complicate the process. In all cases, the aims of the

\footnotetext{
${ }^{57}$ For more information on the composition of the sample, see Appendix B.

${ }^{58}$ Bruce M. S. Campbell, English Seigniorial Agriculture, 1250-1450 (Cambridge, 2000), 58-59, 18387; Barbara Harvey, Westminster Abbey and Its Estates in the Middle Ages (Oxford, 1977), 148-51.
} 
stray system seem to have been remarkably similar; the core idea was to ensure that the process was sufficiently public and transparent so as to give the owners of lost beasts ample opportunity to find and reclaim them. In this section, we reconstruct the complex processes of the stray system, illustrated in figure 1 , as it was administered by manor courts.

The starting point for all cases was for a stray animal to be found within a lordship. This could happen in two ways: either through an ad hoc discovery or via an organized search for unidentified livestock. ${ }^{59}$ In terms of the former, larger animals like horses and oxen were often found on common land. For example, in Wakefield, a suspected stray ox was described as "wandering in the great wood." 60 Strays could also be discovered when they appeared on the lord's land, as when pigs "came into the lord's park as strays."61 Some manors also carried out systematic searches for strays. This practice was most prevalent at manors with large waste and/or common lands. For example, at Little Downham, a manor located within the vast fenland around the Isle of Ely, strays were frequently found on the large fen commons. Here, strays were identified through annual drives performed by the community of tenants, where all unclaimed livestock were collected and identified. ${ }^{62}$ At other times, strays were identified not through an actual "roundup" but through a systematic bureaucratic inquiry. The process did not require the physical presence of the animal at a court session, but instead officials simply created a written memorandum documenting the stray's appearance. Officials at Downham made use of both strategies, and juries regularly made inquiries into strays that had recently come onto the manor. ${ }^{63}$ For instance, in 1428, the jury was ordered to "inquire of all strays existing inside this lordship both inside the park and inside the marsh.” These animals were then meant to be presented at the next court. ${ }^{64}$

Once a stray animal was found, the discovery needed to be "registered" at the next session of the manor court. ${ }^{65}$ Sometimes this involved actually bringing the animal to the session, perhaps to ensure that it could be identified by the community. In 1297, Adam Francis was ordered to bring a set of pigs "thought to be strays" to the next court at Wakefield, and similar orders were given at various sessions at this manor between 1307 and 1338. ${ }^{66}$ This public registration of strays had several benefits for lords. Perhaps most importantly, it identified the existence of an asset in their

\footnotetext{
${ }^{59}$ Unfortunately, the records do not generally provide much detail about the former process, although strays seem to have been found in common areas, on peasants' property, or on the lord's land. For example, in several cases of "stray" bees, the court at Worfield noted that these had been found in the trees of various tenants, presumably as hives migrated. See 17 October 1384, SA, P314/W/1/1/151; 5 October 1385, SA, P314/W/1/1/156; 2 December 1392, SA, P314/W/1/1/184; 4 October 1419, SA, P314/W/1/1/254.

${ }^{60}$ John Lister, ed., Court Rolls of the Manor of Wakefield, 1315-1317 (Cambridge, 1930), 157.

${ }^{61}$ K. M. Troup, ed., The Court Rolls of the Manor of Wakefield from October 1338 to September 1340 (Leeds, 1999), 12.

${ }^{62} 4$ October 1435, EDR, C11/2/6, m.28; c.8 September 1439, C11/2/6, m.31; 3 September 1447, EDR, Cll/2/6, m.39.

${ }^{63} 30$ September 1434, EDR, C1l/2/6, m.26; c. 8 September 1439, C11/2/6, m.31.

6422 September 1428 , EDR, Cll/2/6, m.14.

${ }^{65}$ The court rolls usually use the term "presented" for this process, but we call it "registration" here to avoid confusion with the separate process of "proclaiming."

${ }^{66}$ William Paley Baildon, ed., Court Rolls of the Manor of Wakefield, 1274-1297 (Cambridge, 1901), 7, 70. See also Sue Sheridan Walker, ed., The Court Rolls of the Manor of Wakefield from October 1331 to September 1333 (Leeds, 1983), 19, 192; Troup, Wakefield, 1338 to 1340, 19.
} 


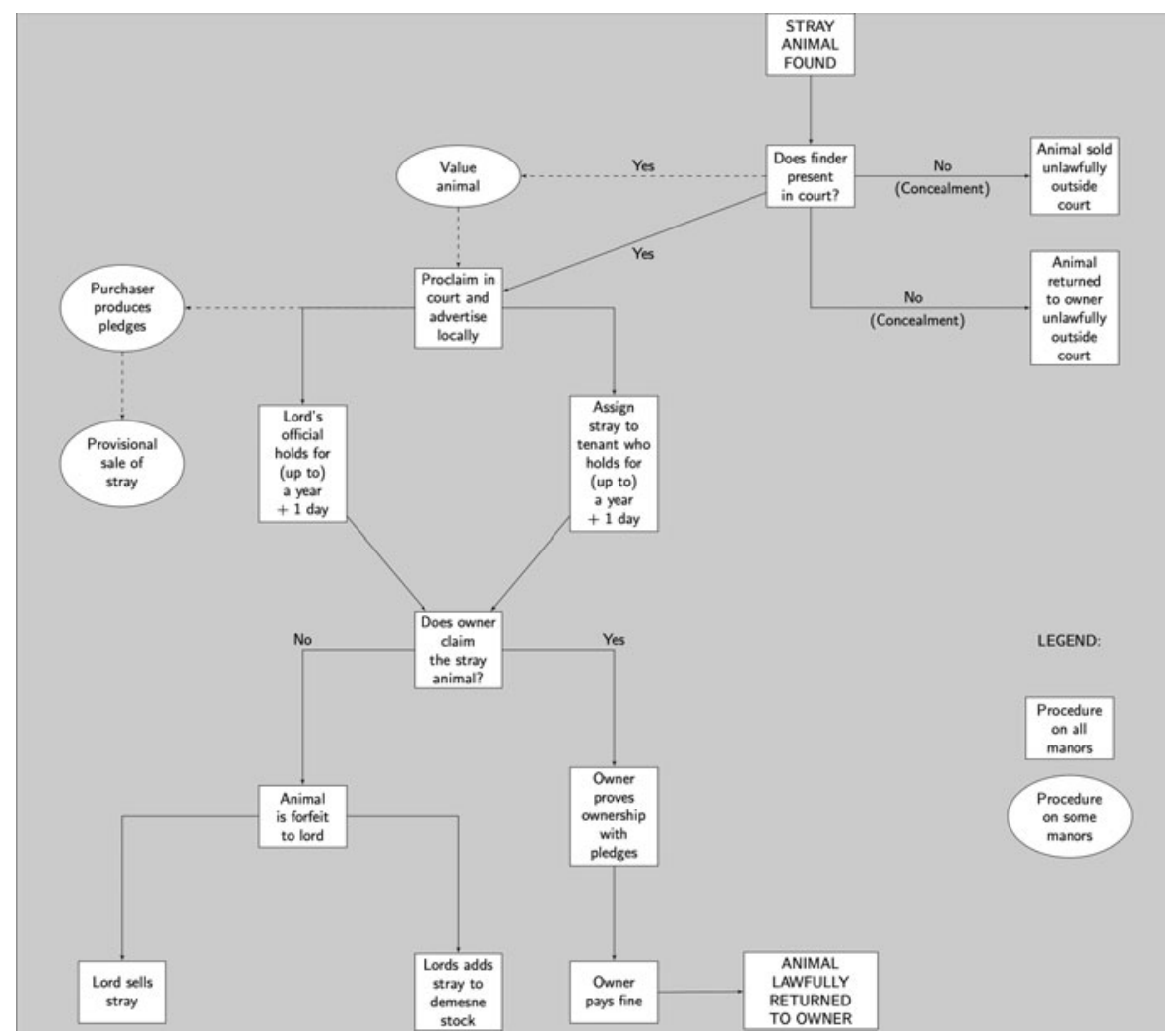

Figure 1-Flow Chart of Stray System

lordship that they could potentially later claim as their own property. It also meant that lords could establish where, and with whom, the animal was being kept, and therefore assign responsibility if an animal was subsequently injured or lost. Such concerns can be seen in inquiries into the death of strays at Worfield and Downham. ${ }^{67}$ At Worfield in 1385, a former reeve was amerced 12d. "for negligence" because "at the time he ought to have guarded . . . an ox." 68 Any ambiguity over the provenance of strays created problems. A 1275 case from Wakefield involved a stray that had not been properly taken and presented, so that it was hard to establish who was ultimately responsible for its loss. Initially, the entire township of Walton, a village within the larger manor of Wakefield, was ordered to answer for a stray bullock "that [had been] among them" for around four months between the feast

${ }^{67} 28$ October 1415, SA, P314/W/1/1/244; 2 May 1365, EDR, C11/1/2, m.14; 18 February 1408, EDR, Cll/2/4, m.18; 3 December 1420, EDR, Cll/2/5, m.15; 19 July 1426, EDR, Cl1/2/6, m.9; 12 July 1429, EDR, Cll/2/6, m.16; c.1432, EDR, Cll/2/6, m.21; c. 1443, EDR, C11/2/6, m.35.

${ }^{68} 12$ April 1385, SA, P314/W/1/1/154. 
of St. Giles and Christmas but had "afterwards [been] sent away by them."69 In the subsequent court, the township responded to this accusation by arguing that, while the stray had been present "going about in the town and in the fields," it "was not in anybody's custody who could be made responsible for it." The stray had then been seized by Ralph Pykard (via his servant) from nearby Normanton, a village outside Wakefield. Ralph's servant was therefore held responsible, allowing the township to be absolved of any wrongdoing. ${ }^{70}$

At several manors, the registration process explicitly involved a valuation of the animals, which could occur even before a beast was necessarily forfeit to the lord. ${ }^{71}$ At Worfield and Downham it is on occasion explicitly stated in the rolls that these valuations were made in court by manorial juries or tenants. ${ }^{72}$ These initial valuations were presumably undertaken so that any loss could be charged to the person holding the animal if a defect of care occurred. For example, in 1413 the reeve of Worfield was ordered to exact from William Preests a fee of $12 \mathrm{~d}$., the value of a horse in William's guard that "ran off by negligence of the same William." 73

Valuing a stray shortly after it was found also worked to prevent fraud by officials. Accordingly, in 1393, the court at Worfield ordered that a former reeve, Thomas de Rugge, pay $4 \mathrm{~s}$. because he had rendered only $7 \mathrm{~s}$. for a stray cow that had been valued at 11s. in his account. ${ }^{74}$ Similarly, in 1308 at Wakefield, a grave (a manorial official acting on behalf of the lord) was amerced $24 \mathrm{~d}$. for "concealment" because he had not charged himself in the court roll for a stray horse he had purchased for himself or for another stray horse he had sold. ${ }^{75}$ Finally, valuation also helped lords recover the value of strays that fell into the hands of outsiders, either by accident or sometimes by deliberate theft. ${ }^{76}$ For instance, when the jury at Tooting Bec, Surrey, presented that Richard Bradwatere had carried off a stray hog, the lord could order that its value of $16 \mathrm{~d}$. be claimed from Richard's goods and chattels. Thus, even if the stray was gone, its value could still be realized. ${ }^{77}$

Despite the registration and valuation mechanisms, the administration of the stray system could be vulnerable to fraud. Court rolls reveal a range of presentments against officials who attempted to circumvent procedure in the manor court in order to profit from stray animals directly. ${ }^{78}$ For instance, at Worfield, in part of a larger set of abuses, Thomas Jenkins, a former reeve, was found to have "seized one cow. . . which came of an outsider or of stray, which . . . he did not present in the court." Then, "without warrant of the steward or. . . council of the lord [he]

${ }^{69}$ Baildon, Wakefield 1274-1297, 135.

70 Baildon, 140 .

${ }^{71}$ Oram, Tottenham 1377-1399, 8, 54, 58, 106, 160, 233; Court Rolls of the Manor of Rickinghall,10 November 1320, British Library, Additional MS. 63432.

728 May 1368, SA, P314/W/1/1/68; 12 April 1385, SA, P314/W/1/1/154; 5 March 1450, EDR, Cll/

2/6, m.46; 4 March 1455, EDR, Cll/2/6, m.50.

739 May 1413, SA, P314/W/1/1/241.

${ }^{74}$ c. 1393, SA, P314/W/1/1/212; Gibbs, "Lords, Tenants and Attitudes," 161.

75 Baildon, Wakefield 1297-1309, 157.

${ }^{76}$ Oram, Tottenham 1377-1399, 282; Baildon, Wakefield 1297-1309, 2; Walker, Wakefield 1331 to 1333, 148; 12 November 1360, TNA, DL 30/129/1957, m.51; 1 April 1411, EDR, C11/2/4, m.27.

77 London County Council, ed., Court Rolls of Tooting Beck Manor (London, 1909), 38.

7830 November 1384, SA, P314/W/1/1/152; 14 February 1369, EDR, C11/1/2, m.18. 
delivered the [stray] cow out of the liberty."79 Similarly in 1410 at Downham, the reeve, Thomas Colleson, delivered two stray bullocks "without claim in court." 80 In both cases, the lord's officials circumvented the stray system and simply gave the animals back to their original owners, presumably pocketing for themselves the fee owed to the lord.

Officials could also commit fraud by selling stray animals for their own profit. For example, at Wakefield in 1275, the lord's sergeant was found, among other illicit activities, to have sold a stray sheep forfeit to the lord. Thomas Colleson, noted above, committed a similar fraud when he sold, at Ely Market, a foal born of a stray horse. ${ }^{81}$ Defrauding a lord by abusing the stray system was not the preserve of officials alone; tenants also occasionally attempted to cheat the system. The easiest way for a tenant to abuse the system was simply to not report the discovery of strays in court. ${ }^{82}$ At Wakefield, in 1315 and 1316, tenants were presented for taking and concealing stray animals. ${ }^{83}$ Particularly audacious was the case of William de Godeley Jr., who was presented at court for selling a stray ox at Wakefield. When the ox, for reasons left unstated, "returned to William's house," he sold it for a second time to a second buyer. ${ }^{84}$ Deliberate attempts to circumvent the system could be interpreted as an affront to the lord's authority. Such cases were certainly described in these terms in the court rolls, which ultimately reflect the lord's perspective. However, we might also interpret these cases from the tenants' point of view.

In cases like the ones discussed above, when a lord's official circumvented the manor court but still returned a stray animal to its original owner, the owner obviously stood to benefit from the evasion. In such a scenario, an owner likely colluded with the official and presumably paid a smaller fee than a lord would exact, or even no fee at all, to get their animal back. Individual tenants and officials would obviously stand to profit from such an arrangement. However, concealment would have had further-reaching negative effects on trust and cohesion within the larger village community and beyond. Ultimately, the stray system was designed to return lost animals to their original owners. For that to work, it needed to be both public and transparent. Concealment, especially if the animal was sold outside the stray system by the concealer, would have deprived a tenant of the ability to reclaim an important capital asset and ultimately undermined the integrity of the stray system.

Once an animal was brought to the court and registered as stray, the system required it to be "proclaimed." This essentially meant that news of the discovery had to be "advertised" or disseminated both inside the community and in other nearby public forums, according to the law. This was the fundamental aspect of the stray system that allowed claimants to locate and recover their lost animals.

7927 September 1406, SA, P314/W/1/1/234. See also Gibbs, "Lords, Tenants and Attitudes," 163.

${ }^{80} 4$ December 1410, EDR, C11/2/4, m.26.

${ }^{81}$ Baildon, Wakefield 1274-1297, 112; 4 December 1410, EDR, C11/2/4, m.26.

${ }^{82}$ Oram, Tottenham 1377-1399, 286; J. Amphlett, ed., Court Rolls of the Manor of Hales, 1272-1307, pt. 1 (Oxford, 1910), 264; 4 October 1347, TNA, DL 30/129/1957, m.17; 6 February 1357, TNA, DL, 30/ 129/1957, m.41; 5 May 1405, SA, P314/W/1/1/233.

${ }^{83}$ John Lister, ed., Court Rolls of the Manor of Wakefield, 1313-1316 (Cambridge, 1917), 81; John William Walker, ed., Court Rolls of the Manor of Wakefield, 1322-1331 (Cambridge, 1945), 41, 128.

${ }^{84}$ Lister, Wakefield 1313-1316, 117. 
How did the proclaiming process work? While most court roll entries simply state that animals "are to be proclaimed," 85 "were proclaimed," 86 or "hav[e] been proclaimed," 87 at Tottenham and Alrewas some entries are more prescriptive and explicitly mimic the precise language of the franchisal law, stating that proclamations should occur "in the market place and church." 88 At the latter manor, one stray foal was claimed by the bailiff of the precentor of Lichfield after being "cried twice in Lichfield fair and three times in the church."89 Similarly, in 1327, the court at Wakefield ordered that Thomas Alayn, into whose care a stray steer was entrusted, was "to have it proclaimed for three days in the Wakefield market." " In 1358, at Bradford, a stray was said to have been "multiple times proclaimed everywhere," 91 while, in 1444, at Elmley Castle, strays had been proclaimed "in various foreign districts." 92 These proclamations were effective in spreading news about strays, as the information traveled across a relatively wide geographical area. Figure 2 illustrates the impressive reach of these advertisements by plotting the home villages of individuals who successfully claimed strays at Little Downham's manor court. As can be seen, claimants came from as far as ten miles away to recover their lost animals. This was a significant distance in the medieval world, the round trip requiring a whole day's travel. ${ }^{93}$

After a stray beast had been proclaimed, it entered a period of legal limbo where no one person could claim to truly be its owner. Stray animals remained in this stage of the system until they were either claimed or were forfeit to the lord after a year and a day. As one can imagine, there were practical concerns around maintaining an animal during this period. This responsibility was shared by the lord and the community. On some manors, the lord's officials were responsible for maintaining the animals, while on others tenants actively collaborated with lords to care for the beasts and uphold the integrity of the stray system. At Downham, the custody of strays seems to have been largely the remit of seigniorial officials, as strays were held in the

8527 July 1388, EDR, Cl1/1/3, m.21; 7 April 1402, EDR, C11/2/4; 7 April 1427, EDR, Cl1/2/6; Robert K. Field, ed., Court Rolls of Elmley Castle, Worcestershire, 1347-1564 (Worcestershire, 2004), 113.

${ }^{86} 17$ October 1349, TNA, DL 30/129/1957, m.20. See also transcriptions by Dorothy Jamieson at Bedfordshire Archives and Records Service (hereafter this repository is abbreviated as BARS, and all citations are to court rolls): 13 October 1394, BARS, R box 212, R8/62/1/1 m.2; 11 October 1407, BARS, $\mathrm{R}$ box 212, R8/62/1/3, m.3; 10 October 1414, BARS, R box 212, R8/62/1/4, m.7; see also Court Roll 38a, 18 November 1448, BARS, Willington Index, https://bedsarchives.bedford.gov.uk/CommunityHistories/Willington/WillingtonIndexOfPages.aspx.

${ }^{87}$ London County Council, Court Rolls of Tooting Beck, 64, 120, 220

${ }^{88}$ Oram, Tottenham 1377-1399, 54, 58, 308; Court Rolls of the Manor of Alrewas (all subsequent references to this collection are court rolls), 9 January 1328, Staffordshire Record Office, Stafford (hereafter this repository is abbreviated as $\mathrm{SRO}), \mathrm{D}(\mathrm{W}) \mathrm{O} / 3 / 9 \mathrm{~m} .5 ; 14$ May $1328, \mathrm{SRO}, \mathrm{D}(\mathrm{W}) \mathrm{O} / 3 / 9 \mathrm{~m} .11$; 6 May 1329, SRO, D(W)O/3/9 m.8.

8925 June 1328, SRO, D(W)O/3/9, m.11.

${ }^{90}$ Walker, Wakefield 1322-1331, 101.

916 November 1358, TNA, DL 30/129/1957, m.45.

92 Field, Elmley Castle 1347-1564, 111.

${ }_{93}$ The thirteenth-century jurist Henry de Bracton asserted that markets should not be closer than six and two-thirds miles to each other because "every reasonable day's journey consists of twenty miles." See Thorne, Bracton on the Laws and Customs of England, 198. For a discussion in the context of medieval Devon, see Maryanne Kowaleski, Local Markets and Regional Trade in Medieval Exeter (Cambridge, 1995), 285. 


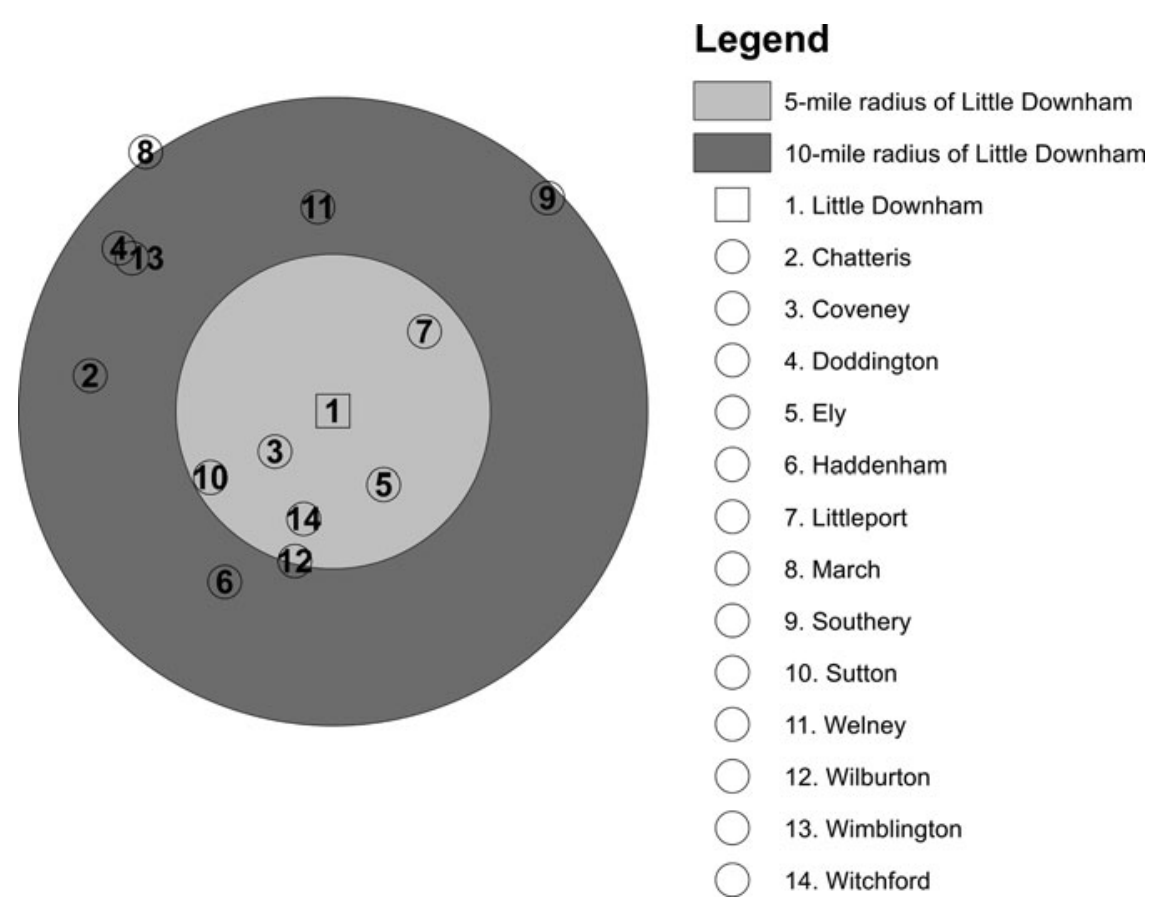

Figure 2-Home Villages of Claimants to Strays at Little Downham's Manor Court. Sources: CUL, EDR, C11/1/2-3, C11/2/4-6.

bishop's 250 -acre park. ${ }^{94}$ At Worfield, in contrast, strays were frequently assigned to individual tenants. Of the 386 strays whose guardians can be traced in the court rolls for 1353-1450, just under 80 percent were looked after by tenants rather than officials. Guardianship was spread throughout the tenant community; over 157 individuals cared for two animals each, on average. ${ }^{95}$ This phenomenon of entrusting strays to individual tenants can also be seen at Wakefield, Willington, Bradford, and Elmley Castle. ${ }^{96}$ Having custody of a stray did not mean that the tenant had legal ownership of the animal, and courts clearly recognized this distinction. ${ }^{97}$

${ }^{9}$ c. 1432, EDR, Cll/2/6, m.21; 24 September 1433, EDR, C1l/2/6, m.24; date damaged, EDR, Cll/2/6, m.35; 28 May 1449, EDR, C11/2/6, m.43; M. Clare Coleman, Downham-in-the-Isle: A Study of an Ecclesiastical Manor in the Thirteenth and Fourteenth Centuries (Woodbridge, 1984), 4.

95 1353-1450, SA, P314/W/1/1/34-303.

${ }^{6}$ Walker, Wakefield 1322-1331, 107; also Dorothy Jamieson Transcriptions: 13 October 1394, BARS, $\mathrm{R}$ box 212, R8/62/1/1 m.2; 10 October 1425, BARS, R box 212, R8/62/1/1 m.4; 25 October 1404, BARS, R box 212, R8/62/1/3, m.3; 22 October 1415, BARS, R box 212, R8/62/1/4, m.6; 22 October 1422, BARS, CR 31; 18 November 1448, BARS, CR 38a; 11 November 1453, BARS, CR 42a; Dorothy Jamieson, Willington and the Mowbrays: After the Peasants' Revolt (Woodbridge, 2019), 113; 17 March 1354, TNA, DL 30/129/1957, m.30; 11 December 1359, TNA, DL 30/129/1957, m.49; 8 June 1361, TNA, DL 30/129/1957, m.56; Field, Elmley Castle 1347-1564, 76, 130.

97 The distinction is drawn out in an example at Worfield, where, in 1394, the beedle was ordered by the court to account for a horse "formerly existing in the custody of William Chese for 8 weeks . . . after the 
For claimants to get their animal back, they had to provide certain assurances. Strays had to be "proved" or "haymalded" by the original owner as part of a public process. Typically, the claimant appeared in court with between three and twelve "hands": individuals who would vouch that the stray indeed belonged to the person claiming it. ${ }^{98}$ As with many medieval legal processes, these hands had to be "trustworthy" men. ${ }^{99}$ For example, in 1390 at Tottenham Bruces, Thomas Benworth of Walthamstow came with "true men of the neighbourhood" to "prove" his calf. ${ }^{100}$ This process could also be carried out by an agent acting on behalf of the actual claimant, such as a servant acting for a master, or a family member acting for a relative who was perhaps a minor. ${ }^{101}$ In addition to proving ownership, claimants were sometimes required to demonstrate that the stray animal in question had not been stolen or been in the possession of thieves while out of their care. ${ }^{102}$

The only legally legitimate way to recover a stray animal was through the manor court. Circumvention of the court system, even by the original owner, was punishable by amercement. Simply put, once a stray had been discovered and entered the system, an owner could not just go and take it back. Claimants had to recover their animals through the stray system. This was designed to prevent illegitimate claims, but perhaps most importantly, to protect the transparency upon which the system depended. A number of cases illustrate this point. ${ }^{103}$ In an unusually detailed example from Wakefield in 1331, William, son of William del Hirst, was arraigned for taking two stray mares held in the custody of Thomas de Stainland. William admitted that he had indeed taken the strays but claimed that his actions were permissible, as the two mares were his property. Nevertheless, because he had circumvented the system, he was fined $12 \mathrm{~d}$. for taking the mares without the bailiff's license. ${ }^{104}$

same was arrested for doing a felony." Here, the beast was still considered a stray, and therefore was not forfeit to the lord as a felon's goods typically were on this manor. If legal ownership had transferred with custody of the stray, the horse would have been forfeit to the lord. 30 June 1394, SA, P314/W/1/ 1/189; see also Gibbs, "Felony Forfeiture at the Manor of Worfield," 253-77.

${ }^{98}$ For example, see D. L. Powell, H. Jenkinson, and M. S. Guiseppe, eds., Court Rolls of the Manor of Carshalton from the Reign of Edward III to that of Henry VII (London, 1916), 26-27; 17 March 1354, TNA, DL 30/129/1957, m.30; Field, Elmley Castle 1347-1564, 2, 116; 10 September 1386, EDR, Cll/1/3, m.16; 9 September 1387, EDR, Cll/1/3, m.18; 2 August 1390, EDR, C1l/1/3, m.25; September 1391, EDR, C1l/1/3, m.28; 5 December 1392, EDR, Cll/1/3, m.31; 3 December 1395, EDR, Cll/1/3, m.38; 26 November 1398, EDR, C1l/1/3, m.43; 29 November 1400, EDR, C11/2/ 4, m.4; 26 July 1401, EDR, Cll/2/4, m.5; 4 March 1406, EDR, Cll/2/4, m.15; 17 December 1415, EDR, Cll/2/5, m.5; 23 December 1429, EDR, Cll/2/6, m.17; Walker, Wakefield 1331 to 1333, 34, 120; 16 April 1454, SA, P314/W/1/1/308.

${ }^{99}$ Ian Forrest, Trustworthy Men: How Inequality and Faith Made the Medieval Church (Princeton, 2018), 53-56.

${ }^{100}$ Oram, Tottenham 1377-1399, 54.

${ }^{101}$ Baildon, Wakefield 1274-1297, 84, 102, 191; 7 March 1402, EDR, C11/2/4, m.7.

102 Powell, Jenkinson, and Giuseppe, Manor of Carshalton, 26-27; 17 March 1354, TNA, DL 30/129/ 1957, m.30; Field, Elmley Castle 1347-1564, 80. The requirement to prove that a stray animal had not been with thieves was because a lord's claim to stolen goods overrode the rights of the original owner of a stray; see Gibbs, "Felony Forfeiture at the Manor of Worfield," 263.

${ }^{103}$ Walker, Wakefield 1331 to 1333, 19; Troup, Wakefield 1338 to 1340, 174; 22 January 1356, TNA, DL 30/129/1957, m.37.

${ }^{104}$ Walker, Wakefield 1331 to 1333,168 . That this amercement was for circumvention of the stray system has been inferred by the authors because William was not presented for either theft or for infringing the lord's right of stray. 
Strays could be returned to owners outside of an actual court sitting, but this still had to be approved by a seigniorial official. ${ }^{105}$ Even once strays were returned, several courts had procedures to ensure that if a second claimant subsequently appeared with a genuine claim, the owner could still recover the property. This was typically done through a pledging system, where the original claimant had to find one or more pledges. Similar to the hands discussed above, pledges were "trustworthy" men from the community. Rather than simply vouching for the legitimacy of an individual's claim to a stray, as hands did, a pledge was made responsible for either producing the animal or providing its value, if another (legitimate) claimant came forward within a year and a day of the stray's original discovery. ${ }^{106}$ Therefore, a claimant's property rights were always protected by the system, even if the court had initially allowed another to (illegitimately) recover a stray, so long as a claim was made within a year and a day.

Once the myriad stages of the stray system are broken down, it becomes clear that it was heavily biased toward claimants who could rely on a public system not only to find and secure a lost animal but also to protect largely unalienable rights to claim the stray within a 366-day window. Despite these rights, a significant number of stray animals went unclaimed. Evidence from Downham, where it is possible to track animals over time, reveals that of 299 strays that can be tracked between 1365 and 1449, around 57 percent were not claimed. ${ }^{107}$ When this happened, unclaimed animals became the property of the lord. In several cases, lords then took the animals into their own hands for their own uses. Working animals were often taken for the lord's demesne. Court rolls sometimes illuminate such transfers, as in 1274 at Wakefield when two horses and a cow went unclaimed and were subsequently ordered to be placed with the earl's stock. ${ }^{108}$ Account evidence reveals that the acquisition of strays augmented other seigniorial perquisites, like heriots (a death due, usually tenants' best beast, owed to their lord), and provided lords with a significant source of demesne livestock. ${ }^{109}$ When lords put an acquired stray draft animal to work on their farm, it often displaced an incumbent of lower quality. ${ }^{110}$ When non-working animals fell to the lord, they were sometimes simply consumed. At Downham in 1450, a black bullock valued at an exceptional 9s. 6d. fell to the lord and was slaughtered "in hospitality of the lord to the use and welcome of the lord."111 As Downham was a rural retreat of the bishop of Ely, the beast was likely slaughtered for the bishop and his guests.

\footnotetext{
1057 July 1433, EDR, C11/2/6, m.23.

106 Court Rolls of the Manor of Worlingworth, 14 June 1323, HAl16/3/19/1/2, m.15, Suffolk Record Office, Ipswich Branch, Ipswich; Field, Elmley Castle 1347-1564, 2; Baildon, Wakefield 1274-1297, 84, 97, 100, 134, 164, 169, 171, 191, 192, 238, 258; Lister, Wakefield 1313-1316, 56; Walker, Wakefield 1331 to 1333, 81, 85, 120; 7 July 1259, SRO, D(W)0/3/1, m.1; Court Rolls of the Manor of Alrewas, 14 December 1298, TNA, SC2/202/56.

${ }^{107}$ Exact proportions: 57 percent fell to the lord, 30 percent were claimed, 3 percent were embezzled, 4 percent died, and 5 percent are unknown. 1365-1399, EDR, C11/1/2-3; 1399-1449, EDR, C11/2/4-6.

${ }_{108}$ London County Council, Tooting Beck, 220; Baildon, Wakefield 1274-1297, 97.

109 Claridge, "Role of Demesnes," 15.

${ }^{110}$ Jordan Claridge, "The Trade of Agricultural Horses in Late Medieval England" (PhD diss., University of East Anglia, 2015), 94.

${ }^{111} 5$ March 1450, EDR, Cll/2/6, m.46. See also 19 July 1426, EDR, C11/2/6, m.9.
} 
Lords often chose simply to realize the value of acquired strays through sale. This option presumably offered greater flexibility, especially as many of the stray draft animals acquired by lords would have been of lower quality than those employed in demesne agriculture. ${ }^{112}$ Indeed, many of the stray horses that fell to demesnes would have been surplus to requirements and were therefore quickly "flipped" for cash. ${ }^{113}$ At some manors, such as Worfield and Bradford, sale seems to have been almost universally favored. At Worfield, sales are described as being made "by the steward" and "in full court." 114 This means that sales of stray livestock were public, ensuring that tenants had first access to the unclaimed strays that had fallen to the lord. At other manors, sales seem to have been managed differently. At Elmley Castle, strays were often sold to the tenants who had guarded them for the requisite 366-day claiming period. The possibility of securing permanent ownership perhaps suggests an incentive for tenants to maintain strays well. ${ }^{115}$

Bradford saw this arrangement taken a stage further, with stray animals being sold before the end of the 366-day period and thus being placed in the custody of these purchasers. However, the sale explicitly did not obviate the claim of the original owner. Much as when strays were claimed, purchasers were required to provide pledges to ensure that they would produce the animal or its value if a claimant later appeared within the allotted time period. ${ }^{116}$ At the same time, payment to the lord could be delayed until after the 366-day period had elapsed, meaning that purchasers did not lose their investment. ${ }^{117}$ Tenants at Bradford seem to have been allowed right of first refusal for animals found as strays. In an example from 1353, three stray foals were given to the Brothers of Pontefract because "none will buy them." 118 Of course, the difficulty of finding a buyer in this case may well have been an effect of dampened demand and economic uncertainty in the wake of the Black Death. On rare occasions, strays were sold in bulk. An entrepreneurial individual might have been able to lease or purchase the right to buy prospective strays, as seemingly happened at Wakefield when all the strays found in the accounting year 1350-51 were sold in advance to William Mirefield for a flat sum of 10s. ${ }^{119}$ This particular sale also may have been an exceptional response in the aftermath of

\footnotetext{
112 Claridge, "Trade of Agricultural Horses," 126; Langdon, Horses, Oxen and Technological Innovation: The Use of Draught Animals in English Farming from 1066-1500 (Cambridge, 1986), 250.

113 Claridge, "Trade of Agricultural Horses," 94; For the "rigidity" of demesne livestock numbers on the Bishop of Ely's manor of Wisbech Barton, see also David Stone, Decision-Making in Medieval Agriculture (Oxford, 2005), 114.

1143 November 1369, SA, P314/W/1/1/73; 15 November 1371, SA, P314/W/1/1/85; 14 May 1372, SA, P314/W/1/1/86; 4 November 1372, SA, P314/W/1/1/87; 6 October 1374, SA, P314/W/1/1/97; 14 June 1375, SA, P314/W/1/1/99; 19 November 1375, SA, P314/W/1/1/100; 2 May 1379, SA, P314/W/ $1 / 1 / 117 ; 24$ October $1413, S A, P 314 / W / 1 / 1 / 242$. This practice mirrors evidence for the sale of felons' goods at this manor; see Gibbs, "Felony Forfeiture at the Manor of Worfield," 269.

115 Field, Elmley Castle 1347-1564, 130, 134-35, 143.

11616 April 1358, TNA, DL 30/129/1957, m.43; 12 January 1361, TNA, DL 30/129/1957, m.52.

1176 August 1355, TNA, DL 30/129/1957, m.36; 22 January 1356, TNA, DL 30/129/1957, m.37; 23 May 1356, TNA, DL 30/129/1957, m.39; 6 February 1357, TNA, DL 30/129/1957, m.41; 2 October 1357, TNA, DL 30/129/1957, m.42; 16 April 1358, TNA, DL 30/129/1957, m.43; 19 June 1359, TNA, DL 30/129/1957, m.47; 12 January 1361, TNA, DL 30/129/1957, m.52.

118 February 1353, TNA, DL 30/129/1957, m.26.

${ }^{119}$ Moira Habberjam, Mary O'Regan, and Brian Hale, eds., The Court Rolls of the Manor of Wakefield from October 1350 to September 1352 (Leeds, 1987), 259.
} 
plague, but other bulk sales were not unheard of, as was the case at Downham in 1452 when twelve strays were sold to Roger Davy, described as "of Ely."120

Overall, however, the discussion above suggests two significant conclusions about the exercise of franchisal rights to strays in late medieval England. Firstly, there was a robust and sophisticated procedure that was heavily biased toward legitimate claimants, ensuring that any owners had the right to claim their stray within the year and a day, as stipulated in the franchise. Courts worked to ensure that strays were publicly registered and then widely proclaimed within the 366-day period. The system also punished both officials and tenants who tried to profit illicitly from animals or simply failed to guard them properly. The rights of claimants were protected in all circumstances.

Secondly, this system necessitated the significant involvement of a large number of the lord's tenants. These obviously included the seigniorial officials, drawn from among the peasantry, who managed strays, but it also extended beyond this to encompass the broader community. In terms of involvement in the stray system, tenants not only utilized the court to present strays but also acted as jurors or a general collective to assign valuations to these animals. They often became responsible for the custody of the animals over the 366-day claiming period. Moreover, this system provided the additional benefit of allowing tenants the opportunity to purchase unclaimed strays, giving community members access to a relatively cheap stock of animals. In this way, the system is akin to that described by Johnson for wreck courts, where the system provided a way to legitimately realize the value of found objects. ${ }^{121}$

Of course, it could be argued that there were more efficient ways to provide the public good of policing strays. One hypothetical alternative would be a finderskeepers model, where those who found a stray simply got to keep the animal. Another would have been a system at the village level that cut out the lord completely. In this second scenario, there would have been no need to pay a fee to the lord for custody upon a claim, nor would it have been necessary to buy strays from the lord. Under such a hypothetical situation, the lord would not have had the ability to take strays for his own stock or consumption. However, even in the unlikely scenario that lords would have allowed such an undercutting of their authority, a solely village-run institution would not have offered the protection guaranteed by the public process of the lord's court and its ability to coerce those who flouted the system through financial penalties. While other systems could have provided protection against destruction of crops by animals, they could not simultaneously preserve the property rights of the original owner.

\section{COULD LORDS PROFIT FROM THE STRAY SYSTEM?}

Our analysis suggests that the stray system protected the property rights of tenants, serving their purposes as much as their lord's. However, this conclusion raises an obvious question: did administering the system bring lords a windfall of profits? When strays were claimed back by their owners, lords received a fee. In addition,

\footnotetext{
12024 May 1452, EDR, C11/2/6, m.49.

${ }^{121}$ Johnson, "Economics of Shipwreck," 125; Johnson, "Medieval Law and Materiality," 425-27.
} 
if animals went unclaimed after the 366-day period, lords, either by adding the animal to their stock or by selling it, realized its value.

But any such income derived from the stray system needs to be weighed against the costs of administering it. This section addresses this issue with a hypothetical exercise, asking whether it would have been possible for lords to turn a profit on the stray system. We illustrate that, due to a range of constraints imposed by the legal institutions underpinning the stray system, it would have been difficult, if not impossible, for most lords to profit from the system even if they had wanted to. To illustrate we conceive of a situation where lords did try to profit from the system. What would this look like? What conditions would have to be met for lords to gain in a meaningful way from wielding the franchise of strays?

In this exercise, we focus only on stray horses, which are the best available test of the stray system. Within the wide range of livestock that came into the system, horses appeared most frequently, and accordingly they represent the largest group in our sample. Out of our total of 1,066 stray observations, 393 were horses, comprising 36.9 percent of the total sample (see table 1). Cattle are also a large group (256 animals accounting for 24 percent of the total), but the great range of types and variations in maturity of these beasts makes any quantification impossible. Horses, on the other hand, were a rather more homogenous group of animals, and there is sufficient surviving quantitative evidence to model both lords' costs in maintaining horses and the potential payoff they could have received if the animals ultimately fell to them. Oxen could be modeled similarly, but the sixteen observations in the sample are too few to draw meaningful conclusions. Horses were also a more expensive beast to buy and keep than sheep or pigs and therefore are the obvious case study to pursue here. ${ }^{122}$

The costs that lords would have incurred in keeping a stray horse for the requisite 366-day period could include a range of components. The largest by far would have been fodder, and there were also other obvious costs in maintaining a working animal. Horses were frequently shod with metal shoes, and the stables or barns in which they were kept had to be maintained. On a more theoretical level, one might also figure depreciation into the equation. The year and a day that lords were required to keep stray animals was a significant portion of a horse's effective working life of around ten years, so the animals clearly lost value as they aged. ${ }^{123}$

Taking all these elements into account, we have created two maintenance cost estimates for every year between 1250 and 1450, a high estimate that includes all the components discussed above, and a low or bare-bones estimate that only includes fodder costs and is basically the amount required to simply keep an animal alive. The specific composition of each estimate and the relevant methodological concerns are described in Appendix A. These are illustrated, along with discrete values of individual stray horses, in figure 3 . Over the two centuries from 1250 to 1450 , the

\footnotetext{
122 Bees also make up a relatively large part of our sample (182 observations, accounting for 17 percent of the total sample). However, the difficulty of tracing the owner of these animals, unlike other strays, means that they were seemingly immediately sold for a small fee to the person who found them. Thus they do not follow the typical path of animals in the system. See Baildon, Wakefield 1274-1297, 293; 24 October 1384, SA, P314/W/1/1/158; 30 September 1395, SA, P314/W/1/1/195.

${ }^{123}$ John Langdon, "The Economics of Horses and Oxen in Late Medieval England," Agricultural History Review 30, no. 1 (1982): 31-40, at 36, esp. table 4.
} 
Table 1-Composition of Stray Animals

\begin{tabular}{lcc}
\hline Type of animal & Number of observations & Percentage \\
\hline Horses & 393 & 36.9 \\
Cattle & 256 & 24.0 \\
Bees & 182 & 17.1 \\
Sheep & 173 & 16.2 \\
Pigs & 43 & 4.0 \\
Oxen & 16 & 1.5 \\
Geese & 3 & 0.3 \\
Total & 1066 & 100 \\
\hline
\end{tabular}

Sources: SA, P314/W/1/1/31-303; CUL, EDR, C11/1/2-3, C11/2/4-6; Baildon, Wakefield 1274-29; Baildon, Wakefield 1297-1309; Lister, Wakefield 1313-1316; Lister, Wakefield 1315-1317; Walker, Wakefield 1322-1331; Helen M. Jewell, The Court Rolls of the Manor of Wakefield from September 1348 to September 1350 (Leeds, 1981); Walker, Wakefield, 1331 to 1333; Habberjam, O'Regan and Hale, Wakefield 1350 to 1352; Troup, Wakefield 1338 to 1340; TNA, DL 30/129/1957; Oram, Tottenham 1377-1399; Jamieson Transcriptions: BARS, R Box 212; London County Council, Tooting Beck; British Library, Additional MSS. 63428-51; SROI, HAl16/3/19/1/2-5.

average cost of maintaining a horse for 366 days would have been around $115 \mathrm{~d}$. at a high level and $102 \mathrm{~d}$. at the bare-bones level of subsistence. As our maintenance estimates are driven by fluctuating grain prices, maintenance costs were substantially higher in the famine years of 1315-1317 and following the Black Death in 13501352. A third spike is observed in 1369, which Bruce Campbell has attributed to a "combination of dearth and plague" in a period of bad harvests and recurring plague episodes. ${ }^{124}$ In any event, the cost of maintaining a stray horse was centered around 100d., or $8 \mathrm{~s} .4 \mathrm{~d}$., for most of our period. That amount would have been equivalent to forty days' wages for a semi-skilled worker, such as a thatcher, in 1300 when such a job paid 2.5d. per day, or twenty-two days' pay in 1400 when wages had climbed to $4.5 \mathrm{~d} .{ }^{125}$

To calculate a cost/benefit analysis, the lords' outlays need to be balanced against the income they could generate through the stray system. The first revenue channel was the fines that claimants paid to retrieve their stray animals from the lord. The court rolls unfortunately do not record this information systemically, but we were able to glean twenty-eight observations, which appear in table 2 . As can be seen, these retrieval fines tend to cluster in distinct groups. Claimants usually paid either $3 \mathrm{~d}$., $6 \mathrm{~d}$., or $12 \mathrm{~d}$., to reclaim their animals. These rates are typical of the wider range of manor court fines and amercements at the time. When described in the court rolls, the fines are justified as either for keeping the animal or, more generally, as a fee for claiming. ${ }^{126}$ What is obvious is that these fines are so low that it would have been difficult for lords to make any significant profit from them.

\footnotetext{
${ }^{124}$ Campbell, English Seigniorial Agriculture, 7.

125 Christopher Dyer, Standards of Living in the Late Middle Ages: Social Change in England, c. 12001520 (Cambridge, 1989), 215.

126 Baildon, Wakefield 1274-1297, 238-39; Baildon, Wakefield 1297-1309, 70, 140; Lister, Wakefield 1313-1316, 87, 91, 169; Lister, Wakefield 1315-1317, 44, 56, 157; Walker, Wakefield 1322-1331, 22; Walker, Wakefield 1331 to 1333, 34, 81, 120; Troup, Wakefield 1338 to 1340, 12; Field, Elmley Castle
} 


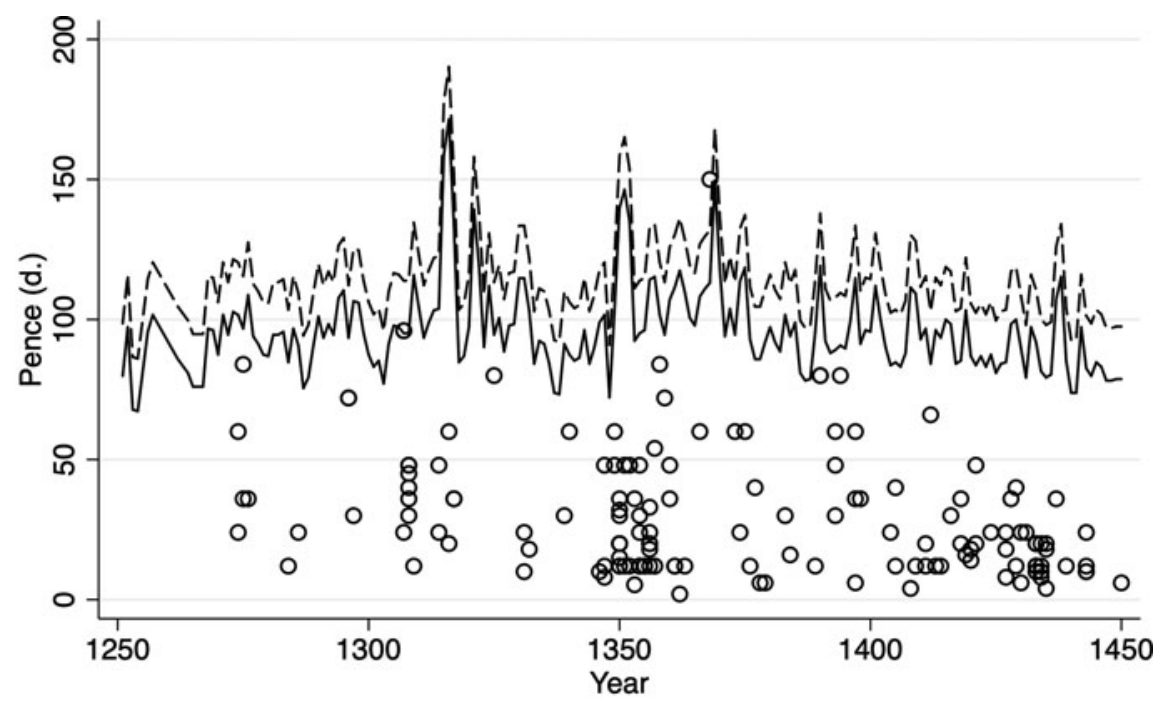

○ Stray horse value ----- High maintenance cost

Low maintenance cost

Figure 3-Comparison of Stray Horse Values with "High" and "Low/Bare Bones" Maintenance Costs. Sources: Stray values: SA, P314/W/1/1/31-303; Baildon, Wakefield 1274-1297; Baildon, Wakefield 1297-1309; Lister, Wakefield 1313-1316; Lister, Wakefield 1315-1317; Walker, Wakefield 1322-1331; Jewell, Wakefield 1348 to 1350; Walker, Wakefield 1331 to 1333; Habberjam, O'Regan and Hale, Wakefield 1350 to 1352; Troup, Wakefield 1338 to 1340; TNA, DL 30/129/1957; Oram, Tottenham 1377-1399; Jamieson Transcriptions, BARS, R Box 212; London County Council, Tooting Beck. Maintenance costs: see Appendix A.

Table 2 compares the fines paid by claimants against lords' maintenance costs. The table provides the number of days of maintenance that any individual fine would have financed. As can be seen, these fines, on average, would have covered only twenty-nine days' maintenance costs, and most strays spent significantly more time under the lord's care. Fortunately, Downham's court rolls provide enough information to estimate the number of days that some stray horses spent in the lord's care before being claimed. In all fifteen cases, the lord held the animal for significantly longer than would have been profitable. A case of 1370 described in the Year Books supports this view. A plaintiff (clearly of high status, if not a lord himself) sued a certain lord for refusing to return his stray mule. The defendant argued that he had retained the mule justly, as the fee of $2 \mathrm{~s}$. offered by the plaintiff (through his bailiff) "was too little, for the [month] that the mule was in the defendant's keeping." 127 This fine of $2 \mathrm{~s}$. is much greater than the average fine of $9 \mathrm{~d}$, , yet it

1347-1564, 80; 9 September 1448, EDR, Cll/2/6, m.41; 4 December 1398, SA, P314/W/1/1/208; Powell, Jenkinson, and Guiseppe, Manor of Carshalton, 26-27.

127 Year Book, Easter 44 Edward III, fol. 14a, 30, Seipp no. 1370.053, https://www.bu.edu/phpbin/ lawyearbooks/search.php (search by Seipp number). It is hard to take this case at face value. Prorating the amount of 2 s. over a year works out to 24 s. or $288 \mathrm{~d}$., 49 percent greater than our 366-day "high" 
Table 2-Stray Fines in Comparison to Maintenance Costs

\begin{tabular}{|c|c|c|c|c|c|}
\hline Year & Manor & Animal & $\begin{array}{l}\text { Amount } \\
\text { given for } \\
\text { keeping (d.) }\end{array}$ & $\begin{array}{l}\text { Number of days } \\
\text { in which lord } \\
\text { could make } \\
\text { profit }\end{array}$ & $\begin{array}{c}\text { Actual days held } \\
\text { by lord } \\
\text { before claimed } \\
\text { (Downham only) }\end{array}$ \\
\hline 1275 & Wakefield & Foal & 12 & 45 & - \\
\hline 1275 & Wakefield & Stotts (2) & 12 & 23 & - \\
\hline 1275 & Wakefield & Foal & 6 & 23 & - \\
\hline 1296 & Wakefield & Mare & 12 & 47 & - \\
\hline 1296 & Wakefield & Horse & 12 & 47 & - \\
\hline 1307 & Wakefield & Filly & 6 & 23 & - \\
\hline 1308 & Wakefield & Mare and foal & 12 & 46 & - \\
\hline 1315 & Wakefield & Affer & 12 & 28 & - \\
\hline 1316 & Wakefield & $\mathrm{Ox}$ & 12 & 44 & - \\
\hline 1323 & Worlingworth & Mare & 4 & 16 & - \\
\hline 1332 & Wakefield & Mare and foal & 3 & 11 & - \\
\hline 1365 & Little Downham & Mare & 3 & 11 & 39 \\
\hline 1369 & Little Downham & Mare & 12 & 29 & 87 \\
\hline 1369 & Little Downham & Mare & 6 & 15 & 87 \\
\hline 1369 & Little Downham & Mare & 12 & 29 & 329 \\
\hline 1369 & Little Downham & Mare & 24 & 59 & 329 \\
\hline 1382 & Little Downham & Mare & 4 & 17 & 101 \\
\hline 1385 & Little Downham & Mare & 9 & 33 & 308 \\
\hline 1392 & Little Downham & Mare & 12 & 50 & 98 \\
\hline 1398 & Little Downham & Ox & 12 & 51 & 214 \\
\hline 1401 & Little Downham & Mare & 12 & 39 & 282 \\
\hline 1402 & Little Downham & Mare & 6 & 22 & 214 \\
\hline 1410 & Little Downham & Horse & 6 & 24 & 310 \\
\hline 1412 & Elmley Castle & Foal & 4 & 17 & - \\
\hline 1429 & Little Downham & Foal & 4 & 15 & 183 \\
\hline 1431 & Little Downham & Foal & Nothing & 0 & 371 \\
\hline 1434 & Little Downham & Mare & 6 & 27 & 291 \\
\hline Avg. & & & 9 & 29 & 216 \\
\hline
\end{tabular}

Sources: Baildon, Wakefield 1274-1297; Baildon, Wakefield 1297-1309; Lister, Wakefield 1313-1316; Lister, Wakefield 1315-1317; Walker, Wakefield 1331 to 1333; CUL, EDR, C11/1/2-3, C11/2/4-6; SROI, HAl16/3/19/1/2-5; Field, Elmley Castle 1347-1564.

was argued that the amount was still insufficient to cover the costs of maintaining this particular mule.

If lords could not generate any significant revenue from fining claimants, the only remaining profit channel would be to benefit in some way from realizing the value of unclaimed strays. Figure 3 compares all of the values of stray horses contained in our sample against the high and low annual maintenance cost estimates. This analysis reveals that both maintenance cost estimates consistently

cost estimate for 1370 . This suggests that the excessive costs sought in this case were actually to cover damage done by the mule or even just personal animosity between the two parties. 
exceeded the values of stray horses, with very few exceptions, over the duration of our study. Even the very conservative bare-bones cost, which includes only enough food to keep the animal alive and assumes no loss in value over the time it was held, is consistently higher than the values that lords could expect to realize from any single stray horse. Put simply, the costs of maintaining a stray horse for 366 days would almost inevitably outstrip the animal's value, whether a lord ultimately decided to keep the beast for his demesne or to sell it for cash. In this paradigm, it would have been difficult, if not impossible, for lords to profit in any meaningful way from the stray system. The one real exception to this pattern is the horse discussed above, worth an abnormally high 13s. 4d., which appeared at Tottenham Pembrokes in 1393. ${ }^{128}$ If this horse had gone unclaimed, the joint lords of the manor would have stood to make a profit of around 4s. ${ }^{129}$ However, the horse subsequently escaped into a neighboring lordship and was seized by this other manor's bailiff. This particular horse was likely an unusually valuable stray, as Tottenham's clerk took the unusual step of noting that the lord's counsel should be sought on this matter.

Figure 4 plots the values of stray horses in our sample against the average national price for plow horses, as compiled by David Farmer. ${ }^{130}$ It is immediately apparent that the values of the strays in our sample were not only significantly less than the annual cost of their upkeep but also much lower than cost of the average plow horse. How can we explain the persistently low values of these animals? The most obvious reason is that they were simply of low quality. Many examples from the court rolls support this conclusion. Stray horses were often described as "infirm," "disabled," or "debilitated," and in 1331 the clerk at Wakefield noted that a foal was sold for $10 \mathrm{~d}$., a price that was "so little because [the foal] is of no value."131 Similar indications of low quality can be found for other animals, with a range of other beasts also described as "debilitated" as well as "lame" and "weakened."132 Indeed, the jury at Worfield noted a sheep had been valued at 4d., "and not more because [it is] debilitated." 133 More colorful examples include a pig at Wakefield

128 Oram, Tottenham 1377-1399, 282.

129 This figure is based on subtracting both the high and low annual maintenance cost estimates from the horse's value of 13s. $4 \mathrm{~d}$. Using the low estimate, the lord's profit would have been $70.89 \mathrm{~d}$. Using the high estimate, the lord's profit would have been $52.14 \mathrm{~d}$.

${ }^{130}$ We have used Farmer's series for plow horses here because they were, compared to cart horses, the cheaper animal and most similar to the types of stray horses encountered in our sample; see David L. Farmer, "Prices and Wages," in The Agrarian History of England and Wales, vol. 2, 1042-1350, ed. H. E. Hallam and Joan Thirsk (Cambridge, 1986), 745-55, 799-806; David L. Farmer, "Prices and Wages, 1350-1500," in The Agrarian History of England and Wales, vol. 3, 1348-1500, ed. Edward Miller (Cambridge, 1991), 455-61, 508-12.

${ }^{131}$ Walker, Wakefield 1331 to 1333,19 . In this case the low value may have reflected a lack of training or appropriate temperament, rather than a physical disability. For other similar justifications for low-value animals, see court rolls at 16 October 1374, SA, P314/W/1/1/94; 5 November 1352, TNA, DL 30/ 129/1957, m.26; 28 April 1354, TNA, DL 30/129/1957, m.31; 20 April 1355, TNA, DL 30/129/ 1957, m.35; 17 April 1357, TNA, DL 30/129/1957, m.41; see also Lister, Wakefield 1313-1316, 50; Oram, Tottenham 1377-1399, 46.

132 Troup, Wakefield 1338 to 1340, 67; Oram, Tottenham 1377-1399, 223, 308; see also 5 October 1386, SA, P314/W/1/1/165; 29 October 1393, SA, P314/W/1/1/187; 30 September 1434, SA, P314/W/1/1/ 285; 11 July 1356, TNA, DL 30/129/1957, m.39; 16 April 1358, TNA DL 30/129/1957, m.43.

${ }^{133} 14$ June 1375, SA, P314/W/1/1/99. 


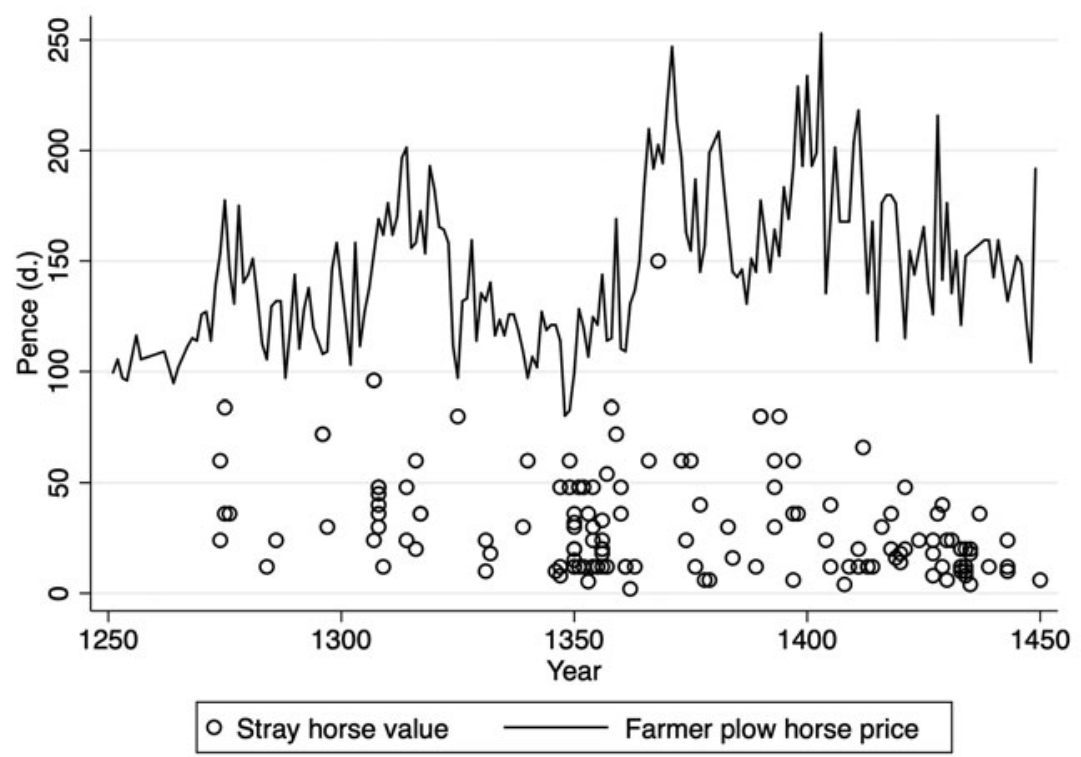

Figure 4-Comparison of Stray Horse Values with Farmer's Annual Plow Horse Price Series. Sources: Stray values: see figure 3. Plow horse prices: Farmer, "Prices and Wages," in The Agrarian History of England and Wales, vol. 2, 1042-1350, ed. H. E. Hallam and Joan Thirsk (Cambridge, 1986), 745-55, 799-806; Farmer, "Prices and Wages, 1350-1500," in The Agrarian History of England and Wales, vol. 3, 1348-1500, ed. Edward Miller (Cambridge, 1991), 455-61, 508-12.

described as "leprous"134 and a bull at Bradford as "insane."135 The low quality was potentially a selection effect. Owners may have released worthless or diseased livestock rather than going to the bother of slaughtering them, or at least expended little effort to recapture such low-quality animals if they escaped.

The very nature of these transactions would have also pushed values down, as these were essentially "fire sales." Having already borne the high costs of upkeep for a year and a day, lords would have been highly motivated to get rid of strays quickly, pushing them into a forced sale. Similarly, as discussed above, the values recorded in the court rolls were most frequently determined by tenant juries when strays first appeared and were registered with the manor court. These juries could have deliberately undervalued stray beasts and would have had reasonably strong incentives to do so, as tenants often ended up purchasing unclaimed stray animals from the lord. But, even if the values of these stray animals were not market prices, they were the sale prices. The value determined in the registration process was essentially binding, and lords, if they sold strays that fell to them, almost invariably received the registered price. ${ }^{136}$

${ }^{134}$ Walker, Wakefield 1322-1331, 39.

${ }^{135} 17$ October 1349, TNA, DL 30/129/1957, m.20.

${ }^{136}$ While the data include both initial valuations and explicit sums paid by purchasers, Elmley Castle, Wakefield, and Worfield's court rolls suggest that animals were nearly always sold for their initial 
Thus, lords ultimately lost money through the stray system because maintenance costs would always outstrip whatever they could make from either fines paid by claimants or by selling or keeping the stray beasts that fell into their hands. Of course, horses are only one type of stray animal, and non-working livestock would have produced goods like wool and milk that could have offset the cost of their maintenance. Similarly, draft beasts had a potential value in the work they could do. However, as demesne farms operated on full stocking regimes, there was likely little value in having an extra and often unsuitable horse to contribute to farm operations. ${ }^{137}$ More generally, the fact that lords often did not maintain strays themselves for the 366-day period but frequently assigned them to tenants suggests that they did not see a significant opportunity for profit. As a process that essentially allowed lords to collect low-quality animals that were unsuited for demesne agriculture and unable to realize a good price at sale after a long period of costly maintenance, the stray system can in no way be seen as being primarily a source of revenue for lords.

\section{CONCLUSION}

We started with a curious narrative about eight animals that had appeared in a small village community in fourteenth-century Cambridgeshire. We hope to have demonstrated that this story is much more consequential than it might first appear. Stray animals were an ever-present feature of rural life in the Middle Ages, and administering scores of such animals had far-reaching implications for the society and economy of late medieval England.

The right to take strays was granted, via formal franchise, by the crown to the most privileged lords. However, on the ground, it was effectively a system run by some of the humblest individuals. Peasants were the actors who found, registered, advertised, and cared for stray beasts. They were the owners who came and claimed their lost animals as well as the people who often ended up buying those whose owners never came forward. This system helped secure and circulate a stock of cheap animals that, while perhaps unsuitable for the demands of commercial demesne agriculture, could be productively utilized by peasants. ${ }^{138}$ In this way, the stray system aided the broader pastoral economy of late medieval England by catalyzing the circulation of animals among the peasantry.

The system had two clear purposes: to protect the property rights of those who had lost animals and to safeguard the agricultural land upon which the whole country depended for its livelihood. These ends were achieved by cooperation between lords and tenants. Lords channeled royal privileges to the local community and utilized their manor courts to ensure the transparent administration of the system

\footnotetext{
"registration" values. In this way, the valuation process matches the system that Johnson found at Wreck Courts where the very act of valuation determined the price; see Johnson, "Medieval Law and Materiality," 427. One exception is seen at Worfield in 1413 , when it was specifically stated that a hive of stray bees was "sold by the steward in full court for $6 \mathrm{~d}$. more than its price." The fact that this was specifically noted suggests a deviation from the norm; see 24 October 1413, SA, P314/W/1/1/242.

137 Stone, Decision Making in Medieval Agriculture, 113.

${ }^{138}$ Langdon, Horses, Oxen and Technological Innovation, 252.
} 
that was vital to protecting claimants' rights. In a society where individuals could, and often did, resort to violence to settle disputes, ${ }^{139}$ such transparency was necessary to maintain social cohesion.

Did lords exercise the franchise of stray for profit? Or did they exercise it for the benefit of the community? We have demonstrated that it was impossible for lords to have profited from the stray system in any meaningful way. Our examination of the costs and potential benefits involved in the management of stray horses proves this point. The fines that claimants paid to lords to reclaim their lost animals were simply too low to have generated any revenue. Further, lords would have spent more on maintaining most strays than they could recoup even if a beast went unclaimed and ultimately fell into their hands. This explains why lords did not attempt to benefit financially from their franchise. Instead, they used their privilege to provide an integral public good to the communities over which they had lordship.

What does our study of stray animals suggest about the role of manorial institutions and lord-tenant relations in late medieval England? Our examination of the stray system supports the growing corpus of revisionist literature that has emphasized the facilitative role played by manorial structures in peasant communities. It demonstrates one way in which lords used their manor courts to coordinate a cooperative solution to a pressing problem for their tenants, rather than as a tool for direct expropriation. The stray system illustrates how seigniorial lords, and their institutions, helped solve a problem that would have been difficult for tenants to resolve by themselves. The reasons for this were not necessarily altruistic. Lords were reliant on a productive peasantry to fill their fields with able-bodied laborers or their coffers with rents-or both. Using their manor courts to provide an essential public good, as they did by administering the stray system, simply made economic sense. While lord-tenant relationships could be, and often were, conflictual, our examination of the stray system illustrates how the manor court could also facilitate cooperation. From this perspective, we might think of the manor court as the glue that allowed for social cohesion and the pursuit of mutual economic benefits.

139 Barbara Hanawalt, Crime and Conflict in English Communities, 1300-1348 (Cambridge, MA, 1972), 261-73; Steven Pinker, The Better Angels of Our Nature: A History of Violence and Humanity (London, 2012), 60-61. 


\section{APPENDIX A}

\section{Calculating Maintenance Costs for Medieval Draft Animals}

We attempt here an estimate of how much it would have cost to maintain working horses in late medieval England. As discussed in the text, many variables are involved in such an estimation, but we have a wealth of data from which to judge the matter.

Many of these components have been meticulously calculated by John Langdon. ${ }^{140}$ As Langdon outlines, there are three main components to consider when calculating these costs:

1. Food and fodder costs. These usually comprised some combination of hay and other more expensive and more calorific grains like oats, but also straw and grass pasture.

2. Other maintenance costs. These would include costs for shoeing, harnessing, and stabling.

3. Depreciation. This component considers the average loss in value of a working animal over time.

We have followed Langdon's methodology except that, while he used fixed average prices for food and fodder costs, we have utilized annually variable grain prices drawn from the work of David Farmer to compute a more accurate annual cost series. ${ }^{141}$

Table Al一Draft Horse Maintenance Cost Estimates

\begin{tabular}{ll}
\hline High estimate & Cost in pence (d.) \\
\hline Fixed costs (from Langdon) & \\
Hay and straw & 24.75 \\
Pasture & 12.00 \\
Shoeing & 9.00 \\
Other & 6.00 \\
Depreciation & 12.75 \\
Annual variable costs (from Farmer) & 30.5 to 134.7 \\
Oats & Cost in pence (d.) \\
Low "bare bones" estimate & 24.75 \\
Fixed costs (from Langdon) & 12.00 \\
Hay and straw & 30.5 to 134.7 \\
Pasture & \\
Annual variable costs (from Farmer) & \\
Oats &
\end{tabular}

\footnotetext{
${ }^{140}$ Langdon, "Economics of Horses and Oxen in Late Medieval England."

${ }^{141}$ Farmer, "Prices and Wages [1042-1350]," 733-45, 787-91; Farmer, "Prices and Wages, 13501500," 432-43, 502-5.
} 


\section{APPENDIX B}

\section{Court Roll Sample and Stray Horse Value Sample}

The empirical basis for this article rests on a corpus of 1,066 observations of stray animals based on a sample of manorial court rolls spanning the years 1274 to 1453 and containing a total of 1,781 court sessions. As table Bl illustrates, these sessions are drawn from nine different manors. The sample is not balanced, with the core manors of Worfield and Little Downham making up a large proportion of the total observations of strays. Similarly, there is a bias toward the post-Black Death period, with the majority of observations coming from the 1350 s onward, as seen in figure Bl.

The sample does have several advantages. It encompasses a wide variety of regions including the North, West Midlands, Home Counties, and East Anglia. It thus captures regions traditionally seen as more commercialized, such as the Thames Basin area around London and East Anglia along with less commercialized areas such as the North East and West Midlands. There is some bias in the sample towards manors with open-field systems and commons. There are two likely explanations for this. First, animals were more likely to escape and therefore stray on such manors, and second, strays posed a more significant threat to crops on open-field manors and therefore tenants had more incentive to catch them. The sample also captures a variety of more powerful lords, including manors held by a mixture of royal, aristocratic, ecclesiastical, and monastic lords.

A subsection of the sample was used to provide values for stray horses. The sample consists of the values reported for stray horses from six manors as shown in figure B2. There are no observations from Downham, Rickinghall, or Worlingworth in the horse subsample. Downham's court rolls provided no values for stray animals, and no horses were among the strays reported with values at Rickinghall or Worlingworth. Wakefield accounts for the majority of the pre-Black Death horse observations and Worfield for the majority of the sample after 1350. As figure B3 demonstrates, the sample is well balanced in terms of horse type, with all types of horses except plow horses being found relatively uniformly throughout the period examined.

Despite the unbalanced nature of our data, the sample is well suited to the quantitative exercise conducted here, as we make no claims about the average cost or value of animals but rather use each observation individually. 
Table B1-Manors Sampled

\begin{tabular}{|c|c|c|c|c|c|c|}
\hline Manor & County & Type of lord & Field system/common lands & $\begin{array}{c}\text { Number of } \\
\text { sessions searched }\end{array}$ & Observations & $\begin{array}{l}\text { Proportion } \\
\text { of total } \\
\text { observations }\end{array}$ \\
\hline Worfield (1351-1450) & Shropshire & Aristocratic & $\begin{array}{l}\text { Common fields and some } \\
\text { enclosure with common } \\
\text { and woodland }\end{array}$ & 413 & 493 & 46.25 \\
\hline Downham (1365-1449) & Cambridgeshire & Ecclesiastical & $\begin{array}{l}\text { Common fields with fen } \\
\text { commons }\end{array}$ & 263 & 340 & 31.89 \\
\hline Wakefield (1274-1351) & West Yorkshire & Aristocratic & $\begin{array}{l}\text { Common fields with some } \\
\text { enclosure }\end{array}$ & 599 & 92 & 8.63 \\
\hline Bradford (1338-1362) & West Yorkshire & Royal & $\begin{array}{l}\text { Common fields with some } \\
\text { enclosure }\end{array}$ & 142 & 80 & 7.50 \\
\hline Tottenham (1378-1398) & Middlesex & Aristocratic/gentry & $\begin{array}{l}\text { Common fields with some } \\
\text { enclosure }\end{array}$ & 108 & 17 & 1.59 \\
\hline Willington (1394-1453) & Bedfordshire & Aristocratic & Common fields & 12 & 17 & 1.59 \\
\hline Tooting Bec (1399-1421) & Surrey & Religious house & Common fields & 51 & 15 & 1.41 \\
\hline Rickinghall (1321-1338) & Suffolk & Religious house & Common fields & 105 & 8 & 0.75 \\
\hline Worlingworth (1321-1326) & Suffolk & Religious house & Enclosed fields & 88 & 4 & 0.38 \\
\hline Total & & & & & 1066 & 100 \\
\hline
\end{tabular}

Court roll sources: SA, P314/W/1/1/31-303; CUL, EDR, C11/1/2-3, C11/2/4-6; Baildon, Wakefield 1274-1297; Baildon, Wakefield 1297-1309; Lister, Wakefield 13131316; Lister, Wakefield 1315-131; Walker, Wakefield 1322-1331; Jewell, Wakefield 1348 to 1350; Walker, Wakefield 1331 to 1333; Habberjam, O'Regan, and Hale, Wakefield 1350 to 1352; Troup, Wakefield 1338 to 1340; TNA, DL 30/129/1957; Oram, Tottenham 1377-1399; Jamieson Transcriptions: BARS, R Box 212; Tooting Beck; British Library, Add. MSS. 63428-51; SROI, HA116/3/19/1/2-5. Lord/field system sources (from sources other than court rolls): Worfield: G. C. Baugh, ed., A History of the County of Shropshire, vol. 4, Agriculture (London, 1989), 72-118; Gibbs, "Felony Forfeiture at the Manor of Worfield," 256-57; Downham: L. F. Salzman, ed., A History of the County of Cambridge and the Isle of Ely, vol. 2. (London, 1948), 90-95; Wakefield and Bradford: Edward Miller, "[Farming Practices and Techniques]: Northern England," in Miller, Agrarian History, 2:399-403; Edward Miller, "[Farming Practices and Techniques]: Yorkshire and Lancashire," in Miller, Agrarian History, 2:185-57; Tottenham: T. F. T. Baker and R. B. Pugh, eds., A History of the County of Middlesex, vol. 5 (London, 1976), 333-39; Willington: P. D. A. Harvey, "[Farming Practices and Techniques]: The Home Counties," in Miller, Agrarian History, 3:254-55; Jamieson, Willington and the Mowbrays; Tooting Bec: H. E. Malden, ed., A History of the County of Surrey, vol. 2 (London, 1967), 129-30; Rickinghall and Worlingworth: Mark Bailey, Medieval Suffolk: An Economic and Social History, 1200-1500 (Woodbridge, 2007), 111-12. Each observation refers to a specific stray animal or set of stray animals (when these cannot be disentangled) reported in the court rolls. 


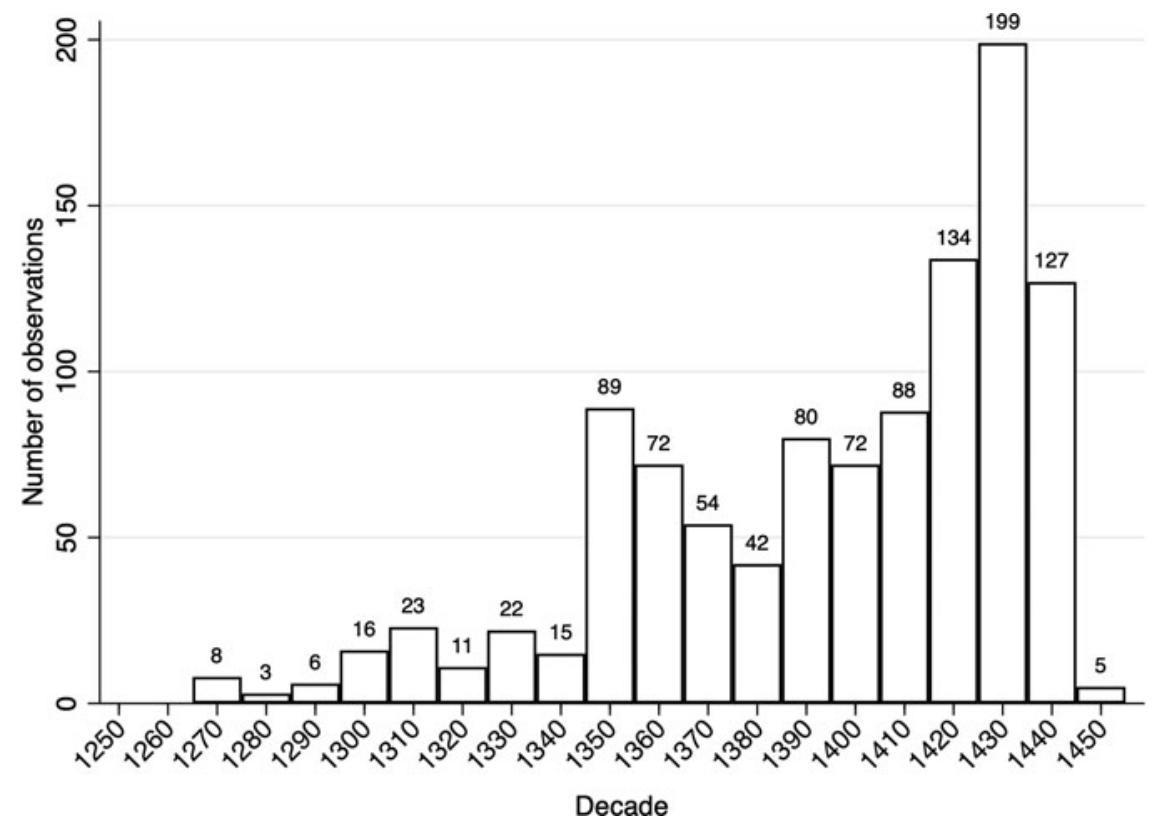

Figure B1-Frequency of Stray Observations by Decade. Sources: See table B1.

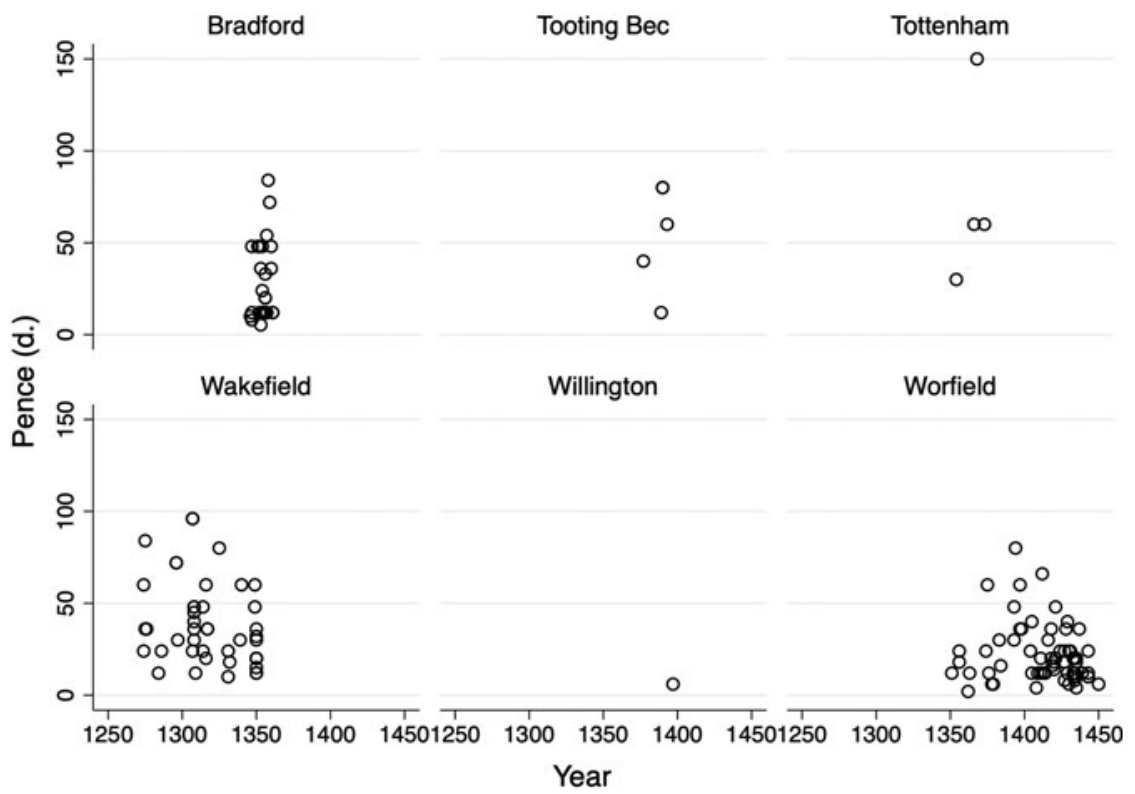

Figure B2-Composition of Stray Horse Sample by Manor. Sources: Worfield: Shropshire Archives, P314/W/1/1/31-303. Wakefield: Baildon, Wakefield 1274-1297; Baildon, Wakefield 1297-1309; Lister, Wakefield 1313-1316; Lister, Wakefield 1315-1317; Walker, Wakefield 13221331; Jewell, Wakefield, 1348 to 1350; Walker, Wakefield, 1331 to 1333; Habberjam, O'Regan, and Hale, Wakefield 1350 to 1352; Troup, Wakefield 1338 to 1340. Bradford: TNA, DL 30/129/1957. Tottenham: Oram, Tottenham 1377-1399. Willington: Jamieson Transcriptions: BARS, R Box 212. Tooting Bec: London County Council, Tooting Beck. 


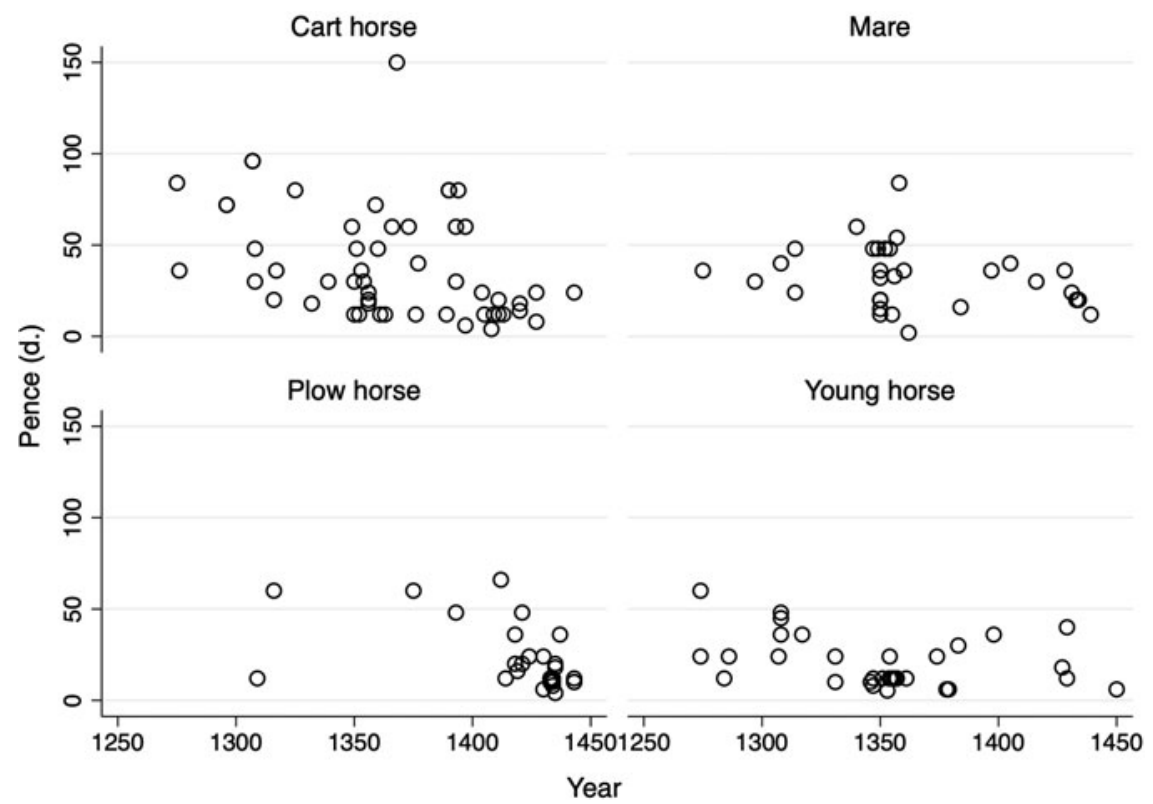

Figure B3-Composition of Stray Horse Sample by Horse Type. Sources: See figure B2. 